
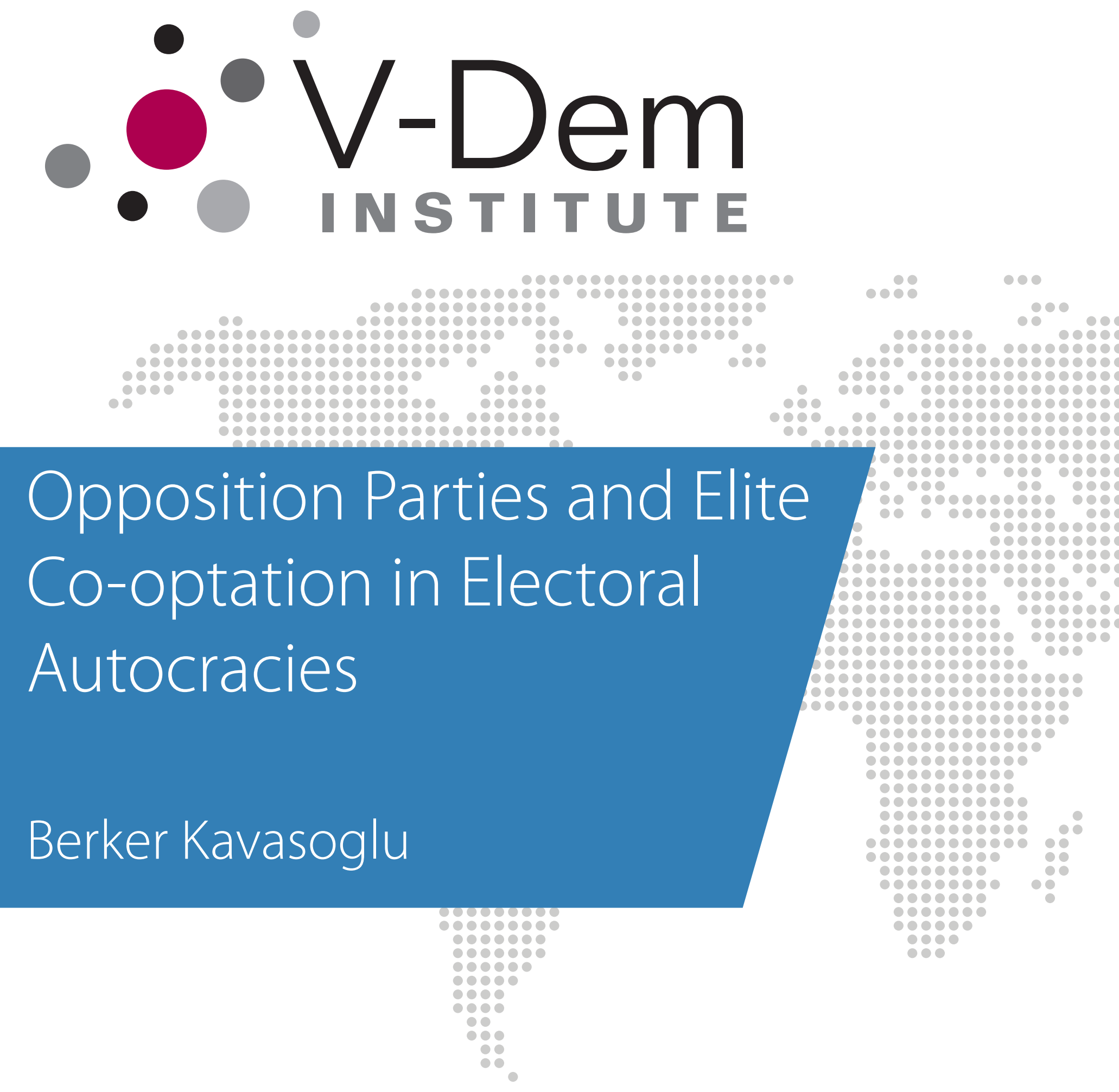

Working Paper

SERIES 2021:120

THE VARIETIES OF DEMOCRACY INSTITUTE 
Varieties of Democracy (V-Dem) is a new approach to conceptualization and measurement of democracy. The headquarters - the V-Dem Institute - is based at the University of Gothenburg with 23 staff. The project includes a worldwide team with 5 Principal Investigators, 19 Project Managers, 33 Regional Managers, 134 Country Coordinators, Research Assistants, and 3,500 Country Experts. The V-Dem project is one of the largest ever social science research-oriented data collection programs.

Please address comments and/or queries for information to:

\author{
V-Dem Institute \\ Department of Political Science \\ University of Gothenburg \\ Sprängkullsgatan 19, Box 711 \\ 40530 Gothenburg \\ Sweden \\ E-mail: contact@,v-dem.net
}

V-Dem Working Papers are available in electronic format at www.v-dem.net.

Copyright (C2021 by authors. All rights reserved. 


\title{
Opposition Parties and Elite Co-optation in Electoral Autocracies
}

\author{
Berker Kavasoglu*
}

\begin{abstract}
Autocratic incumbents often attempt to co-opt select opposition party leaders to minimize threats to their rule. While the literature identifies co-optation of opposition party leaders as an important survival strategy of autocrats in electoral autocracies, we lack a systematic examination of why some opposition party leaders are co-opted but not others. This article argues that opposition party co-optation is shaped by both interand intra-party dynamics. Using a novel data set on opposition party organizations in electoral autocracies between 1970 and 2019, I show that opposition parties with high mobilizational capacity and those that devolve internal decision-making authority from the party leadership to lower cadres are less likely to be co-opted, especially when they are ideological distant from autocratic incumbents. I contend that opposition parties' organizational characteristics and their ideological positioning in an autocratic party system significantly alter the strategic calculus of the incumbent regime and opposition party elites in deciding whether or not to cooperate with one another. Hence, autocratic incumbents' ability to control opposition parties through co-optation is shaped not only by the commonly highlighted factors such as resource availability, institutional manipulation or repression, but also as a result of the relatively less well-understood factors such as opposition party organizational features and party positions.
\end{abstract}

*Varieties of Democracy (V-Dem) Institute, Department of Political Science, University of Gothenburg, Sweden. Contact: berker.kavasoglu@gu.se. This research project was supported by Vetenskapsradet, Grant 439-2014-38, PI: Ellen Lust, University of Gotneburg, Sweden; by Knut and Alice Wallenberg Foundation to Wallenberg Academy Fellow PI: Staffan I. Lindberg, Grant 2018.0144, V-Dem Institute, University of Gothenburg, Sweden; by Vetenskapsradet, Grant 2018-01614, PI: Anna Luhrmann, V-Dem Institute, University of Gothenburg, Sweden. I thank Staffan I. Lindberg, Jonathan Polk, and Anna Lührmann for their support and insightful comments. 


\section{Introduction}

In electoral autocracies where opposition parties are allowed to compete for the national executive and the legislature, autocrats frequently seek to elicit the cooperation of select opposition party leaders to mitigate threats to their rule (Arriola, 2009; Arriola, DeVaro, \& Meng, 2021; Buckles, 2019; Gel'man, 2005; Kelly, 2018; Levitsky \& Way, 2010; Lust-Okar, 2005; Reuter \& Robertson, 2015). They typically do so by providing opposition party leaders with access to patronage resources and making limited policy concessions. In return for these benefits, opposition party leaders are expected to refrain from genuinely challenging the regime. In countries such as Venezuela, Turkey and Russia, autocratic incumbents managed to entrench their rule despite unfavorable circumstances, in part because they succeeded in ensuring the support of select opposition party leaders. ${ }^{1}$ Research suggests that when autocrats manage to co-opt opposition parties, they are better able to prevent anti-regime collective action and survive in office (Arriola, 2009; Gandhi, 2008; Gandhi \& Przeworski, 2007; Lust-Okar, 2005; Reuter \& Robertson, 2015).

Despite the importance of opposition party co-optation in autocracies, our understanding of why some opposition parties are co-opted but not others remains limited. Most studies treat co-optation mainly as an independent variable to understand its implications for opposition fragmentation (Arriola et al., 2021), the nature of dictatorial concessions to opposition groups (Conrad, 2011), mass protest (Lust-Okar, 2005; Reuter \& Robertson, 2015), and regime survival (Arriola, 2009; Gandhi, 2008; Gandhi \& Przeworski, 2007). Studies focusing on the drivers of co-optation are primarily concerned with explaining the incentives and capabilities of autocratic incumbents to co-opt opposition elites (Arriola, 2009; Arriola et al., 2021; Gandhi \& Przeworski, 2006). However, with the exception of a few recent studies based on a small number of cases limited to a single region (e.g. Buckles, 2019; Gandhi \& Buckles, 2016; Kelly, 2018), little has been done to explain which opposition parties are more likely to be co-opted by autocratic incumbents.

In this article, I highlight how internal features of opposition parties interact with the patterns of inter-party competition in shaping the incentives and capabilities of both autocratic

\footnotetext{
${ }^{1}$ Examples of co-opted parties include Just Russia (Russia), Nationalist Action Party (Turkey), Fatherland for All (Venezuela).
} 
incumbents and opposition party leaders to strike co-optation deals. I demonstrate that organizationally extensive opposition parties that are characterized by a nationwide network of permanent local branches together with entrenched ties to prominent social organizations, and those that distribute internal decision-making authority among various party members, are less prone to co-optation. Such organizational features reduce opposition party leaders' incentives to seek political power through co-optation by lowering the costs of maintaining their oppositional stance against the regime, while constraining their ability to bargain with autocratic incumbents. I further argue that ideological distance between an opposition party and autocratic incumbents amplifies the effect of organizational features as it increases the costs of building an alliance on the part of both sides.

Empirically, this article provides the first party-level quantitative analysis on the link between opposition party organizational features, ideological positions, and elite co-optation in electoral autocracies. Using novel party-level data from Varieties of Party Identity and Organization Dataset (V-Party) (Lührmann et al., 2020b) on organizational characteristics and party positions of 328 opposition parties in 64 electoral autocracies between 1970 and 2019, I find empirical evidence corroborating the argument. There is strong evidence that organizationally extensiveness opposition parties, and those with dispersed decision-making structures are less prone to co-optation. Furthermore, there is evidence of interaction effect between party organizational features and ideological distance between opposition parties and autocratic incumbents. The negative effect of organizational extensiveness and the dispersion of internal decision-making authority on the likelihood of co-optation is higher when ideological distance between an opposition party and autocratic incumbents increases. Conversely, party organizational extensiveness and the dispersion of internal decision-making authority exacerbate the negative effect of ideological distance on the probability that an opposition party will be co-opted. The results demonstrate the importance of considering both internal party features and party positions to fully understand how opposition party co-optation works in electoral autocracies.

The key implication of this article is that opposition parties are not simply at the mercy of autocratic institutions and strategic considerations of incumbents; rather they are organizations with varying incentives and qualities that shape their strategies to navigate through 
autocratic constraints. The study's findings call for a greater attention to the mechanisms by which opposition party institutions influence the dynamics of autocratic rule. Previous research overwhelmingly focuses on regime institutions to understand the incentives and capabilities of autocratic incumbents to control political opposition through co-optation. This study shows that how opposition elites are organized is also critical for understanding the conditions under which autocrats are likely to fail (succeed) in their attempts to control opponents through co-optation, contributing to a nascent but growing body of research on opposition parties (e.g. Buckles, 2019; Greene, 2007; Kelly, 2018; LeBas, 2014). Incorporating opposition party organizations to the comparative study of political institutions in autocratic settings can provide an important analytical leverage for the broader research agenda seeking to explain why nominally democratic institutions such as multiparty elections that are intended to perpetuate autocratic rule sometimes sow the seeds of regime change (Bernhard, Edgell, \& Lindberg, 2020; Bunce \& Wolchik, 2011; Schedler, 2013).

\section{Opposition Party Co-optation in Electoral Autocra- cies}

Electoral autocracy has become the modal form of dictatorship in the contemporary world (Schedler, 2006). These regimes hold regular multiparty elections for the chief executive and national assembly, and opposition parties are allowed to recruit candidates, open offices, and run campaigns. Yet, incumbents employ various strategies to skew the playing field in their own favor (Levitsky \& Way, 2010; Schedler, 2013). Under electoral authoritarianism, incumbents often stack electoral commissions and courts with supporters, limit political opposition's access to media, divert public funds for partisan use, and occasionally resort to electoral fraud. Where such institutional manipulations fall short of controlling the opposition, incumbents may employ overt repression. While these strategies can put opposition parties at a significant disadvantage, they can erode the regime legitimacy both domestically and internationally (Bunce \& Wolchik, 2011; Schedler, 2009). Consequently, incumbents often back up institutional manipulations and repression with attempts to elicit cooperation 
of select opposition party leaders to maintain their control over electoral arena and consolidate their rule (Arriola, 2009; Arriola et al., 2021; Buckles, 2019; Gel'man, 2005; Kelly, 2018; Levitsky \& Way, 2010; Lust-Okar, 2005; Reuter \& Robertson, 2015). The key is that co-optation can replace the costly use of flagrant repression and other forms of manipulation.

I define co-optation as an intentional extension of benefits to opposition elites by autocratic incumbents in exchange for their loyalty, acquiescence or cooperation. Autocrats co-opt opposition party leaders by providing them with access to patronage resources, appointing them to key political positions, and/or by making limited policy concessions. In return, opposition leaders are expected to cooperate with the incumbents by supporting their policy initiatives, and by refraining from engaging in anti-regime collective action. Examples of opposition party co-optation include Just Russia (SR) that supported the Russian President Medvedev's policy initiatives during the 2007-2011 parliamentary term; or the National Union for Democracy and Progress's (UNDP) leader Bello Bouba's appointment to the cabinet in 1997 by the Cameroonian President Biya. Although previous research suggests that co-optation of opposition parties is critical for regime survival (e.g. Arriola, 2009; Gandhi, 2008; Lust-Okar, 2005), our understanding of why autocratic incumbents co-opt some opposition parties but not others remains limited.

One strand of research focuses on the incentives and capabilities of autocrats to co-opt political opposition. The conventional wisdom holds that autocrats have greater incentives to resort to co-optation when opposition is capable of threatening regime stability (Gandhi \& Przeworski, 2006). Research suggests that autocratic incumbents often seek to co-opt opposition parties that have demonstrated ability to form an anti-incumbent electoral coalitions with other opposition parties (Gandhi \& Buckles, 2016). Evidence also indicates that autocratic incumbents are more likely to resort to co-optation when their vote share declines (Arriola et al., 2021).

While the threat posed by opposition parties creates incentives for co-optation, the literature also highlights several political and economic constraints limiting the incumbents' capacity of co-optation. Arriola (2009) shows that regimes placing few constraints on the executive, and the availability of economic resources for patronage distribution enhance autocratic incumbents' ability to co-opt opposition elites by appointing them to the cabinet. In 
a recent study, Arriola et al. (2021) further demonstrate that ruling party institutionalization limits the incumbents' flexibility of co-opting opposition elites by enabling regime members to veto co-optation deals that would require them to share rents and spoils with opposition elites.

These works make important contributions, but as some studies increasingly recognize it is also important to consider the conditions under which opposition party elites are willing to accept co-optation offers by autocratic incumbents. Kelly (2018) highlights the importance of having financial endowments and reputation for an opposition party leader to resist cooptation and maintain its oppositional stance over time. Focusing on party organizational characteristics, Buckles (2019) develops a game-theoretic model demonstrating that having a large activist base discourages opposition leaders from cooperating with incumbents given the party activists' incentives to replace the co-opted leader with an alternative leader.

I contribute to this literature by focusing on additional opposition party organizational attributes, and by discussing how inter- and intra-party factors drive patterns of co-optation. In particular, I build on Buckles's (2019) argument that opposition party leaders' incentives to accept a co-optation offer depends on party organizational characteristics. But I discuss how other party organizational attributes such as network of local branches, ties to social organizations, and the dispersion of decision-making authority within opposition parties affect the incentives and abilities of opposition party leaders and autocratic incumbents to forge co-optation agreements. Furthermore, I also theorize about how party organizational features interact with ideological proximity of opposition parties to autocratic incumbents in affecting which opposition parties are more likely to be co-opted. Finally, I present the first party-level quantitative examination of the relationship between time-varying internal characteristics of opposition parties, their ideological orientations, and co-optation events. 


\section{Party Organizations, Ideological Proximity, and Co- optation}

\subsection{Potential Benefits and Risks of Co-optation for Autocrats and Opposition Elites}

Autocrats strive to balance the benefits of co-opting an opposition party against the costs. On the positive side, co-optation can help autocrats avoid the costly use of blatant repression and institutional manipulation. Autocrats can manipulate institutions and use coercion to secure power, but the more they employ such strategies, the greater the risk of opposition backlash (Schedler, 2009). Yet with too little coercion and manipulation they can be overthrown. Co-optation can solve the dilemma by expanding the regime's support base and preventing anti-regime collective action, which together diminish the need for overt repression and manipulation. By selectively targeting some opposition parties while excluding others, autocrats can exacerbate coordination problems within the opposition (Arriola et al., 2021; Lust-Okar, 2005). Thus, autocrats can ultimately neutralize potential threats to their rule and prolong their tenure in office by co-opting opposition parties.

However, on the negative side, co-optation often involves policy concessions and the distribution of patronage resources to opposition elites. Channeling such benefits to political opposition often comes at the expense of a larger distribution of spoils among the members of the ruling coalition whose support is critical for the incumbent leader (see, for example, Bueno De Mesquita, Smith, Siverson, \& Morrow, 2005). When autocrats decide to coopt opposition elites, they risk alienating regime elites, especially the hardliner factions that typically strongly oppose sharing power and spoils with opposition elites. Moreover, in electoral autocracies incumbents value their vote shares. Maintaining their dominance in the electoral arena through large vote margins help them portray an image of invincibility, and preserve legislative majorities required to amend constitutional rules as they wish (Magaloni, 2006). Hence, autocratic incumbents should also carefully consider the views of voters and ensure that co-opting a rival party would not turn the voters away from the regime.

Given these considerations even autocratic incumbents with ample resources face limita- 
tions with regards to the extent of resources they can distribute to opposition party elites. As a result, they must act strategically and seek cooperation of opposition party leaders selectively. One solution is to employ a divide and conquer strategy by selectively targeting some parties but not others (Lust-Okar, 2005). Autocrats often resort to co-optation when faced with political opposition capable to threaten regime stability (Arriola et al., 2021; Gandhi, 2008; Gandhi \& Buckles, 2016; Gandhi \& Przeworski, 2006). Drawing on this logic, we should expect incumbents to seek the cooperation of parties that can credibly threaten the regime without wasting valuable resources for those that do not pose a significant threat. Moreover, autocrats can further make the most out of available resources by targeting opposition parties that regime elites and voters see favorably, at least relative to other opposition parties.

Opposition party elites also need to assess the potential benefits and costs of aligning with autocratic incumbents. On the one hand, forging an alliance with the regime can provide opposition party elites with material benefits, access to political power, and protection from repression. Moreover, opposition party elites can channel the spoils of office to supporters, and build up their reputation in the eyes of constituencies that see the opposition as illegitimate or unsuited to govern (Magaloni, 2006; Rakner \& Van de Walle, 2009). On the other hand, co-optation can alienate party activists and threaten the leader's political survival by triggering internal dissent (Buckles, 2019). For example, Turkey's Nationalist Action Party (MHP) experienced internal rebellion and defections following its leader's decision to align with the Erdogan regime (TurkishMinute, 2017). Moreover, proximate benefits that opposition party leaders could reap from co-optation may come at the expense of broader political reforms and material benefits they could have gained in the future by mobilizing against the regime. For example, opposition parties such as the Movement of Socialist Democrats (MDS) and the Popular Unity Party (PUP) that were loyal to the Ben Ali regime in Tunisia were largely discredited and had little leverage over the design of subsequent democratic institutions in the aftermath of the Jasmine Revolution. ${ }^{2}$

In sum, both autocratic incumbents and opposition party elites need to assess the po-

\footnotetext{
${ }^{2}$ The MDS won only two seats in elections for the Constituent Assembly which was held on 23 October 2011, whereas the PUP failed to win a seat.
} 
tential benefits and costs of striking co-optation deals with one another. As I demonstrate in the following section, the assessments of both sides are to an important degree driven by party-level factors.

\subsection{How Party Organizational Features and Party Positions Drive Patterns of Co-optation in Autocracies}

The argument centers on three party-level factors that shape how autocratic incumbents and opposition party leaders assess the potential benefits and costs of co-optation: (1) organizational extensiveness of an opposition party, involving a nationwide network of visible local branches and ties to social organizations (Duverger, 1959; Kitschelt, 1994); (2) the dispersion of internal decision-making authority within party organizations; (3) and ideological positioning of the incumbent regime and an opposition party.

Opposition parties vary in their capacity to challenge the regime at the ballot box and beyond, as a function of organizational extensiveness. Party organizational extensiveness plays a fundamental role in shaping opposition elites' incentives to align with autocratic incumbents. The boots on the ground provided by local branches enhance the party's capac-

ity to mobilize voters, and help maintain linkages to local party members and constituents overtime (Levitsky, Loxton, Van Dyck, \& Domínguez, 2016; Tavits, 2013). Especially where local-organizational presence is amplified by the ties to prominent social organizations, the opposition party's ability to disseminate its messages and cultivate partisan ties among voters is significantly enhanced (LeBas, 2014; Samuels \& Zucco, 2015). Permanent grassroots presence with the aid of local branches and affiliated social organizations is especially critical in autocratic settings because opposition elites usually have limited access to media, and government censorship hinders their ability to communicate with voters and their membership base (Van Dyck, 2017). Hence, opposition parties with an organized presence on the ground can pose a significant electoral threat to the regime, which provides party leaders with alternative means to push for political concessions and achieve political power. Armed with an extensive party organization, opposition leaders should be less inclined to make costly compromises on their anti-regime stance in exchange for the potential benefits of co-optation. 
Moreover, organizational extensiveness increases the ability of party leaders to compete against the regime beyond the electoral arena. Post-electoral power struggles between opposition parties and incumbents often play a critical role in gradual regime openings and democratic breakthroughs (Bunce \& Wolchik, 2011; LeBas, 2014; Magaloni, 2010; Schedler, 2002, 2013). Given their enhanced mobilizational capacity, organizationally extensive parties have the ability to pose a credible threat of post-electoral revolt, which raises the costs of repression and manipulation on the part of autocratic incumbents (Magaloni, 2010). Consequently, opposition party leaders with extensive organizations face lower costs of remaining in the opposition camp, and thus have relatively fewer incentives to be co-opted than leaders with less extensive organizations.

From the incumbents' perspective, organizationally extensive opposition parties are more valuable to co-opt because they are more threatening to regime stability. Co-opting such parties helps incumbents to play the game of multipartyism without facing the necessity of employing excessively manipulative strategies to remain in power. However, as Buckles (2019) demonstrates opposition parties with a large activist base are likely to demand greater concessions than incumbents are willing to make. When opposition parties have a nationwide organizational infrastructure in the form of local branches and/or ties to prominent social organizations, they are better able to penetrate into constituencies across the nation and mobilize their members and activist base against the incumbent regime. These features further encourage opposition party elites to demand more from incumbents in exchange for their collaboration. However, given that incumbents often have finite resources available to distribute to opposition elites, their ability to co-opt organizationally extensive opposition parties tends to be limited.

Hypothesis 1: Greater party organizational extensiveness is associated with a lower likelihood that an opposition party will be co-opted by the regime.

How opposition party leaders and autocratic incumbents assess the potential benefits and risks of striking a co-optation deal is also shaped by the distribution of power within the opposition party. Party organizations vary in the degree to which decision-making authority over important aspects of party policy (e.g., candidate selection, campaign strategies etc.) is 
concentrated in the hands of an individual party leader, a small circle of elites, or dispersed among various members organized at different layers within the organization. The nature of internal decision-making procedures has important implications for parties' behavior and goals (Panebianco, 1988). Party organizations in which the authority is highly concentrated, party leaders enjoy a greater degree of autonomy and discretion over party strategies. In contrast, the devolution of power to other party elites or lower cadres requires party leaders to seek the approval of various internal veto players before committing to a particular strategy.

Opposition party leaders with greater discretion over party strategies should be more likely to be co-opted than those who need the approval of various internal veto players to strike a deal with incumbents. The literature on coalition formation in democracies demonstrates that when decision-making procedures enable party members to influence party strategies, party leaders' ability to bargain with potential coalition partners is substantially diminished (Strøm, 1994). Similarly, the presence of greater internal constraints on the party leader's decision-making authority should limit the leader's ability to make concessions to the regime and prolong the bargaining process. The decision to align with the incumbent regime often forces party leaders to compromise on their pursuit of broader long-term political gains in exchange for short-term office benefits. Such compromises often meet with a backlash from lower cadres (Buckles, 2019), which typically attach more intrinsic value to the party's confrontational stance against the regime (Buckles, 2019; Greene, 2007; LeBas, 2014). Party leaders can ignore internal demands but doing so puts their hold on leadership at risk, especially when a rival party elite decide to challenge the party leader (Buckles, 2019). Constraints on the party leader stems partly from decentralized leadership selection procedures that enhance the ability of party members to hold the leader accountable. Parties that lack such mechanisms of internal accountability impose fewer constraints on the leaders' ability to make concessions to the regime, reducing the potential costs of co-optation on the part of party leaders.

Autocratic incumbents' ability to co-opt opposition parties with dispersed decision-making procedures is also limited because party leaders with incentives to seek the backing of various party members should be more likely to demand higher concessions from the regime. Party leaders may promise to distribute more spoils and rents to party members, but this requires 
them to push for more expansive deals that are costly for the regime. The demands of party leaders from the regime should increase in parallel to the proportion of party members acting as veto players. Hence, the more dispersed the decision-making authority, the harder it becomes for autocratic incumbents to co-opt the party.

Hypothesis 2: Greater dispersion of intra-party decision-making authority is associated with a lower likelihood that a party will be co-opted by the regime.

The impact of organizational extensiveness and the dispersion of decision-making authority is moderated by the ideological distance between an opposition party and autocratic incumbents. In autocratic party systems, party competition is often two-dimensional. On one dimension, parties usually compete over policy related cleavages such as broader economic conditions or more specific policy areas including, for example, welfare provision, religion in public domain, and the role of the state in the economy. In addition to the policy dimension, the question of regime change is often the most important competitive dimension on which parties are positioned (Greene, 2002). In some autocratic party systems such as Turkey, Venezuela, and Mexico (pre-2000) both dimensions are salient, whereas in other party systems parties have discernible differences in terms of their positions on the regime dimension but not on the policy dimension. I expect the degree to which opposition parties and autocratic incumbents differ in their positioning along the two dimensions to further alter the incentives and capabilities of both sides to forge co-optation deals.

When there is no discernible ideological difference between parties, both sides face fewer constraints when building an alliance. For one, ideological distance exacerbates the costs of co-opting an opposition party on the part of autocratic incumbents due to heightened risk of discontent among ruling elites and the regime's core constituencies. Hardliner internal factions and core constituencies are particularly likely to oppose sharing spoils and rents with an ideologically distant opposition party. When the ideologically distant party has an extensive organization, autocratic incumbents should face especially high costs of co-optation, because organizational extensiveness already creates incentives for opposition party leaders to demand greater concessions from the regime in exchange of co-optation. Importantly, the enhanced risk of alienating a group of regime elites and core constituencies when forming 
an alliance with an ideologically distant opposition party constrains autocratic incumbents even when they have enough resources to meet the demands of an organizationally extensive opposition party. Hence, autocratic incumbents should have fewer incentives and ability to co-opt parties that are both organisationally extensive and ideologically distant from them.

Further, when an opposition party has dispersed decision-making structures, and it is ideologically distant from autocratic incumbents, it becomes less prone to co-optation. If party members and core supporters are ideologically motivated, they are more likely to oppose and veto the party leader's attempt to compromise on the party's oppositional stance. Given that dispersed decision-making procedures enhance the ability of party members to hold the leader accountable, the party leader faces a greater risk of removal from the party leadership if she deviates from the party line. As a result, the party leader is significantly constrained in bargaining with the regime, and in her ability to make concessions to strike a co-optation deal. Conversely, party organizations giving its members few means to constrain the party leader, provides the party leader with fewer incentives to remain committed to the party's ideological position. In this case, the party leader faces a lower risk of punishment by party members, making it less costly to align with the incumbent regime despite ideological differences. The risk of experiencing internal backlash becomes higher for party leaders as the ideological distance between their party and the incumbent regime increases, and this risk should be especially pronounced when an opposition party has dispersed decision-making structures that boost the ability of party members to punish the party leader.

Hypothesis 3: The greater the ideological distance between an opposition party and autocratic incumbents, the stronger the negative association between opposition party organizational extensiveness and the likelihood of co-optation.

Hypothesis 4: The greater the ideological distance between an opposition party and autocratic incumbents, the stronger the negative association between the dispersion of internal decision-making authority and the likelihood of co-optation. 


\section{Research Design}

\subsection{Sample}

I examine these claims on a sample of 328 parties from 64 electoral autocracies-defined as autocratic regimes that hold formally competitive elections for the national executive and the legislature-between 1970 and 2019. ${ }^{3}$ The data set includes repeated observations of major opposition parties ( $>5 \%$ of vote share) across 254 legislative elections, which results in a sample size of 604 party-election-year observations. The unit of analysis is a party-election-year nested in an electoral autocracy.

\subsection{Dependent Variable}

Co-optation is a dummy variable that indicates whether an opposition party joins a preelectoral coalition led by an autocratic incumbent (e.g. Malaysian Chinese Association (MCA), Malaysia 1952 -); an opposition party member accepts a cabinet position after the election (e.g. Senegalese Democratic Party (PDS), Senegal 1992); ${ }^{4}$ an opposition party declares its support for the incumbent's election bid without building a formal electoral alliance with the incumbent (e.g. National Convention Party (NCP), Ghana 1992); and/or if an opposition party provides parliamentary support to the incumbent government (e.g. Liberal Democratic Party of Russia (LDPR), Russia 2000 -). I coded this variable crossing original expert survey data (Lührmann et al., 2020b), ${ }^{5}$ Political Handbook of the World series (1975 - 2019), and cabinet data from Nyrup and Bramwell (2020). A party is coded as co-opted at a party-election-year if any of the aforementioned conditions hold in subsequent years until the next party-election-year. This way of operationalization provides a more conservative test of the hypotheses, but it seeks to mitigate potential simultaneity bias that can be caused by a party's inclusion in a pre-electoral coalition or its declaration of support

\footnotetext{
${ }^{3}$ More information on the sample construction procedure, and the list of elections included in the sample is provided in the Appendix Section 2.

${ }^{4}$ This excludes cases where a party member accepts a cabinet position and consequently resigns or gets expelled from the party.

${ }^{5}$ Appendix Section 3 presents the exact wording of the survey question.
} 
for the incumbent's election campaign. ${ }^{6}$ In total, the data set includes 242 events of cooptation. Section 4 in the Appendix provides the full list of party-election-year observations with co-optation.

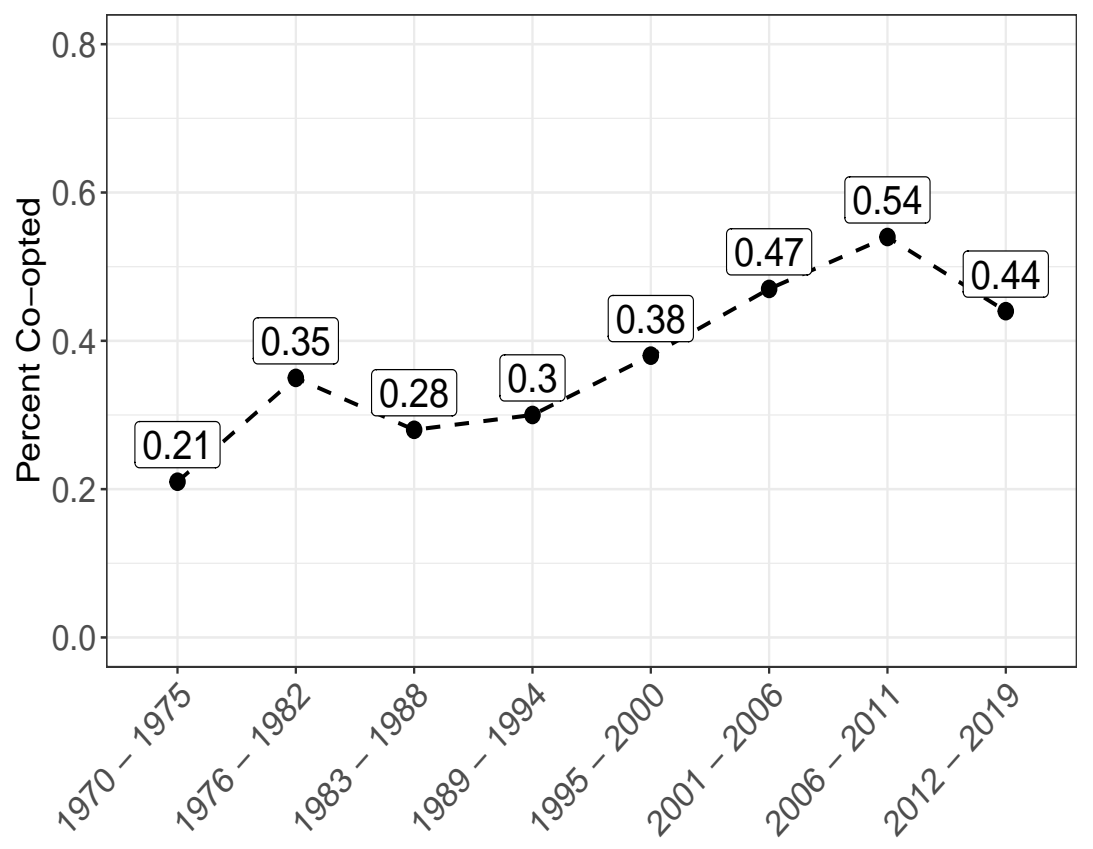

Figure 1: Percent of party-year observations with co-optation between 1970 and 2019.

Figure 1 displays the patterns of opposition party co-optation between 1970 and 2019 . The vertical axis shows the percent of party-election-year observations with co-optation over five to seven year intervals (horizontal axis). The figure demonstrates that co-optation of opposition parties has been prevalent in electoral autocracies, and that there is a clear uptrend since 1970. Opposition party co-optation has become more frequent since the 1990s when many autocracies in sub-Saharan Africa and Central and Eastern Europe introduced multiparty elections. This is in line with the notion that the transition to multiparty politics in these regions have resulted in increasing attempts by incumbents to control opposition party elites through co-optation (Arriola et al., 2021; Gel'man, 2005; Rakner \& Van de Walle, 2009). $2)$.

${ }^{6}$ The results do not change if pre-electoral coalitions are excluded from the analysis (see Appendix Table 


\subsection{Main Independent Variables: Measuring Party Organizational Features and Ideological Positions}

The argument posits that co-optation is a function of internal features of opposition parties and their ideological proximity to the incumbent regime. I use expert survey data collected as part of the V-Party project (Lührmann et al., 2020b). V-Party is the most comprehensive data set on party organizations and party stances to date, allowing this study to present the

first cross-country party-level quantitative investigation of the relationship between party organizational features, ideological stances, and co-optation. The appendix presents the exact wording of the relevant survey questions.

The first part of the argument suggests that organizationally extensive opposition parties is less prone to co-optation. I operationalize organizational extensiveness by building an index composed of three interrelated indicators. The first indicator measures the extent to which a party has a nationwide territorial organization in the form of permanent local branches at the municipal level. The second indicator focuses on the scope of a party's local reach by measuring the degree to which party activists and personnel have an active presence in local communities during and outside the election season. Finally, the third indicator measures the strength of a party's ties to prominent social organizations (i.e., labor unions, business organizations, religious organizations, etc.). The ties are stronger when a party controls prominent social organizations that contribute to its operations by providing material and personnel resources, as well as by helping a party in propagating its message to organizations' members and beyond. The three indicators are standardized and summed together to build the composite index of organizational extensiveness, where higher scores indicate greater extensiveness. The indicators are highly correlated, suggesting that parties that score high (low) in one indicator often score high (low) in other indicators as well (see Table 1 in Appendix Section 5).

To measure the dispersion of internal decision-making authority, I construct an index using two indicators. The first indicator captures the devolution of decision-making authority over the nomination of the party candidates for legislative elections. Lower values on this indicator denote that a party leader has relatively less unilateral power over the nomina- 
tion of the party's legislative candidates, and thus nomination processes are characterized by collegial decision-making procedures incorporating the interests of other party members. The second indicator measures party personalization, which is higher for parties that primarily operate as an instrument to further individual ambitions of a party leader rather than representing the interests of a broader party organization. At extremes, personalized parties are those that provide individual party leaders with full autonomy from other party members without facing effective constraints in setting up party strategies. At the opposite end of the spectrum, non-personalized parties are known with collegial decision-making procedures where party members have more voice in party operations. The two indicators are standardized and summed together to build the composite index of dispersion of internal decision-making authority. The correlation coefficient between the two indicators is strong at 0.44 (see Table 1 in Appendix Section 5). Higher scores on the index indicate increasing dispersion of internal decision-making authority in a party organization.

To test Hypotheses 3 and 4 that suggest the impact of opposition party organizational features is moderated by the ideological distance between an opposition party and the incumbent regime, I utilize two indicators from the V-Party expert survey. The first indicator relates to a party's overall ideological stance on economic issues and captures its position on the left-right scale. I rescaled the indicator to 0-1 through the normal cumulative distribution function, and then calculated the absolute distance between an opposition party and the incumbent party. In contexts where the economic policy cleavage is not salient there is not much observable difference between individual parties, and thus the absolute distance between parties is close to zero. However, the spread of the data suggests that there are notable differences in party positions on the economic policy dimension in autocratic party systems (See Figure 1A and Figure 1E in Appendix Section 5).

The second indicator of ideological positions measures the competition over the question of regime change that is often the most important competitive dimension on which parties are located in autocratic party systems. The measure captures the extent to which the leadership of a party is committed to democratic principles such as free and fair multiparty elections, freedom of speech, media, assembly and association. At one end of the spectrum, a party follows what Greene (2002) calls "regime-mobilizing strategy by promoting itself as 
a party of democratic reform." At the other end of the spectrum, a party openly supports the maintenance of the autocratic form of government. This indicator is also rescaled to 0-1 using the normal cumulative distribution function. I then calculated the absolute distance between an opposition party and the incumbent party. The overall distribution of opposition party positions on the regime dimension highlights that opposition parties vary substantially in the extent to which they seek to promote democratic reforms (see Figure 1B in Appendix Section 5). ${ }^{7}$ The indicator also recognizes the fact that incumbent parties can be democratic reform oriented or highly autocratic, although the former type of incumbent parties are rare (see Figure 1C in Appendix Section 5).

I standardized and combined the two indicators to create a unified measure of ideological distance between an opposition party and the incumbent party. Accordingly, parties that have highly divergent positions on both dimensions score especially high in terms of ideological distance, whereas parties that are located closer to one another on both dimensions score low in terms of ideological distance. The variable ranges from 1.275 to 1.947 with a mean of -0.05 and a standard deviation of 0.783 , suggesting that ideological proximity of opposition parties to autocratic incumbents varies substantially (see Figure $1 \mathrm{G}$ in Appendix Section 5).

\subsection{Model Specification}

I estimate a series of hierarchical logistic models to account for the relationship between party organizational features, party positions, and the likelihood of co-optation. I fit random intercepts logit models, allowing intercepts to vary by party and country, so that the withingroup residuals become conditionally independent and identically distributed. The models incorporate estimated group-level variance components, which would otherwise remain in the error term and result in regressor-error dependency (Snijders \& Bosker, 2012). ${ }^{8}$

\footnotetext{
${ }^{7}$ An opposition party may not be supportive of democratic form government, but it can still be in favor of regime change. As such, the measure may underestimate the distance between an opposition party and the incumbent party on the regime dimension. This should result in more conservative estimates, and thus make it harder to reject the null hypotheses.

${ }^{8}$ This modelling strategy produces more efficient and consistent estimates of rarely changing variables such as party organizational features in small samples than models treating cross-section units as fixed effects (Clark \& Linzer, 2015).
} 
I control for several potential party-level confounding variables. First, the past instances of co-optation may affect organizational features, ideological positions, and the likelihood of co-optation. Accordingly, I control for the number of times a party was co-opted in the past. Controlling for the past instances of co-optation should account for latent factors that make parties previously co-opted by the incumbent regime systematically different than non-coopted parties in ways that are related to party organizational features and ideological stances. Moreover, I add a dummy variable indicating whether a party mainly derives its support from a particular ethnic and/or regional group. I also include a dummy variable for religious parties that often have extensive organizations and dispersed decision-making structures (see, for example, Wegner, 2011). The data on ethnic-regional and religious parties are collected through the V-Party expert survey.

I also control for several variables that are related to the broader competitive environment. These variables account for the possibility that opposition co-optation is driven by incumbents' access to economic resources, socioeconomic context, and institutional framework. One explanation is that the availability of natural resources enhances incumbents' ability to buy off opponents (Arriola, 2009). I use data on oil production per capita to capture the availability of natural resources (Ross \& Mahdavi, 2015). Moreover, in economically developed countries, opposition groups may be more willing to forego material benefits associated with co-optation (Magaloni, 2006), which is likely to create incentives for opposition party leaders to maintain their oppositional stance. To adjust for this possibility, I control for the level of economic development with a measure of GDP per capita from Bolt and Van Zanden (2014).

Previous research demonstrates that presidential systems are associated with party organizational weakness and greater concentration of decision-making authority in the hands of an individual party leader (Rakner \& Van de Walle, 2009; Samuels \& Shugart, 2010). Moreover, in presidential regimes autocrats face few executive constraints that can hinder their ability to co-opt opposition elites (Rakner \& Van de Walle, 2009). Accordingly, the models include a dummy variable for (semi) presidential systems (the reference category is parliamentary system) from Wig, Hegre, and Regan (2015). Finally, opposition groups' ability to invest in party organizations and their willingness to align with the regime should depend 
on the level of regime openness. Regimes that are highly repressive and hold excessively manipulated elections can raise the costs of investing in party organizations and adopting ideologically distant positions from incumbents on the part of opposition elites. To adjust for this possibility, I control for the level of democracy using electoral democracy index from the Varieties of Democracy Project data set (V-Dem) (Coppedge et al., 2020a, 2020b).

While I also control for additional variables in robustness tests, the main models are based on relatively parsimonious specifications that aim to minimize post-treatment bias, and only include aforementioned controls for which there are strong theoretical reasons to be considered as confounders. The main results remain when controlling for additional variables (see Section 5.1).

\section{Results}

Table 1 presents the results predicting opposition party co-optation. Model 1 is the baseline specification only including organizational extensiveness and the dispersion of internal decision-making authority. The coefficients for organizational extensiveness $(\beta=-0.31, p<$ $0.01)$ and the dispersion of internal decision-making authority $(\beta=-0.70, p<0.05)$ are statistically significant and, in line with Hypotheses 1 and 2 both are negatively associated with the probability of co-optation. The results for these variables are only slightly attenuated in Model 2 that also accounts for ideological proximity of an opposition party to the incumbent regime. As expected, the coefficient estimate of ideological distance suggests that opposition parties that are ideologically distant from autocratic incumbents are less likely to be co-opted $(\beta=-1.54, p<0.01)$. Model 3 adds the past instances of co-optation, which is positively associated with the likelihood of co-optation, indicating that opposition parties that have more past experience of collaboration with the incumbents are especially likely to be co-opted in subsequent periods $(\beta=0.80, p<0.01)$. In Model 3 , the estimated co-

efficients for organizational extensiveness, the dispersion of decision-making authority, and ideological distance are similar to Model 2. The results in Models 1-3 remain unaltered in Model 4 that accounts for additional party-level factors by introducing controls for ethnicregional and religious parties. The results suggests that whether an opposition party derives 
its support from a particular ethnic or regional group has no implications for the likelihood of co-optation. However, religion-based opposition parties such Pan-Malaysian Islamic Party (PAS) in Malaysia are significantly less likely to be co-opted than other parties. ${ }^{9}$

Table 1: Party organizational features, ideological positions, and co-optation.

\begin{tabular}{|c|c|c|c|c|c|c|c|}
\hline & Model 1 & Model 2 & Model 3 & Model 4 & Model 5 & Model 6 & Model 7 \\
\hline Organizational extensiveness & $\begin{array}{c}-0.31^{* * *} \\
(0.10)\end{array}$ & $\begin{array}{c}-0.24^{* *} \\
(0.11)\end{array}$ & $\begin{array}{c}-0.24^{* * *} \\
(0.08)\end{array}$ & $\begin{array}{c}-0.23^{* * *} \\
(0.08)\end{array}$ & $\begin{array}{c}-0.22^{* * *} \\
(0.07)\end{array}$ & $\begin{array}{c}-0.24^{* * *} \\
(0.07)\end{array}$ & $\begin{array}{c}-0.21^{* * *} \\
(0.07)\end{array}$ \\
\hline Dispersion of decision-making aut. & $\begin{array}{c}-0.70^{* *} \\
(0.29)\end{array}$ & $\begin{array}{c}-0.55^{*} \\
(0.30)\end{array}$ & $\begin{array}{c}-0.54^{* *} \\
(0.21)\end{array}$ & $\begin{array}{c}-0.62^{* * *} \\
(0.21)\end{array}$ & $\begin{array}{c}-0.57^{* * *} \\
(0.20)\end{array}$ & $\begin{array}{c}-0.52^{* *} \\
(0.21)\end{array}$ & $\begin{array}{c}-0.58^{* * *} \\
(0.20)\end{array}$ \\
\hline Ideological distance & & $\begin{array}{c}-1.54^{* * *} \\
(0.36)\end{array}$ & $\begin{array}{c}-1.35^{* * *} \\
(0.26)\end{array}$ & $\begin{array}{c}-1.34^{* * *} \\
(0.25)\end{array}$ & $\begin{array}{c}-1.35^{* * *} \\
(0.24)\end{array}$ & $\begin{array}{c}-1.33^{* * *} \\
(0.25)\end{array}$ & $\begin{array}{c}-1.39^{* * *} \\
(0.28)\end{array}$ \\
\hline Previous co-optation $(\#)$ & & & $\begin{array}{c}0.80^{* * *} \\
(0.26)\end{array}$ & $\begin{array}{c}0.92^{* * *} \\
(0.26)\end{array}$ & $\begin{array}{c}1.20^{* * *} \\
(0.28)\end{array}$ & $\begin{array}{c}1.21^{* * *} \\
(0.29)\end{array}$ & $\begin{array}{c}1.19^{* * *} \\
(0.29)\end{array}$ \\
\hline Ethnic-regional & & & & $\begin{array}{c}0.26 \\
(0.43)\end{array}$ & $\begin{array}{c}0.23 \\
(0.42)\end{array}$ & $\begin{array}{c}0.20 \\
(0.43)\end{array}$ & $\begin{array}{c}0.22 \\
(0.42)\end{array}$ \\
\hline Religious & & & & $\begin{array}{c}-1.08^{*} \\
(0.64)\end{array}$ & $\begin{array}{c}-1.08^{*} \\
(0.61)\end{array}$ & $\begin{array}{c}-1.19^{*} \\
(0.61)\end{array}$ & $\begin{array}{c}-1.09^{*} \\
(0.61)\end{array}$ \\
\hline Presidential & & & & & $\begin{array}{c}0.24 \\
(0.65)\end{array}$ & $\begin{array}{c}0.24 \\
(0.66)\end{array}$ & $\begin{array}{c}0.25 \\
(0.65)\end{array}$ \\
\hline Electoral democracy & & & & & $\begin{array}{l}-1.70 \\
(1.53)\end{array}$ & $\begin{array}{l}-1.47 \\
(1.55)\end{array}$ & $\begin{array}{l}-1.68 \\
(1.53)\end{array}$ \\
\hline log Oil production pc. & & & & & $\begin{array}{c}0.15 \\
(0.12)\end{array}$ & $\begin{array}{c}0.15 \\
(0.12)\end{array}$ & $\begin{array}{c}0.15 \\
(0.12)\end{array}$ \\
\hline $\log$ GDP pc. & & & & & $\begin{array}{c}-0.77^{* *} \\
(0.33)\end{array}$ & $\begin{array}{c}-0.81^{* *} \\
(0.34)\end{array}$ & $\begin{array}{c}-0.76^{* *} \\
(0.33)\end{array}$ \\
\hline Organizational extensiveness X & & & & & & $-0.15^{*}$ & \\
\hline Ideological distance & & & & & & $(0.09)$ & \\
\hline $\begin{array}{l}\text { Dispersion of decision-making aut. X } \\
\text { Ideological distance }\end{array}$ & & & & & & & $\begin{array}{l}-0.08 \\
(0.25)\end{array}$ \\
\hline $\mathrm{AIC}$ & 564.38 & 484.33 & 475.86 & 476.42 & 467.14 & 466.50 & 469.07 \\
\hline $\mathrm{BIC}$ & 586.40 & 510.42 & 506.31 & 515.56 & 523.33 & 527.02 & 529.59 \\
\hline Log Likelihood & -277.19 & -236.16 & -230.93 & -229.21 & -220.57 & -219.25 & -220.54 \\
\hline Num. obs. & 604 & 572 & 572 & 572 & 557 & 557 & 557 \\
\hline Num. groups: Party & 328 & 312 & 312 & 312 & 308 & 308 & 308 \\
\hline Num. groups: Country & 64 & 63 & 63 & 63 & 62 & 62 & 62 \\
\hline Var: Party (Intercept) & 6.18 & 5.69 & 1.36 & 0.83 & 0.48 & 0.40 & 0.49 \\
\hline Var: Country (Intercept) & 9.53 & 7.54 & 3.81 & 3.81 & 3.18 & 3.57 & 3.19 \\
\hline
\end{tabular}

Hierarchical logit models. Standard errors in parentheses. ${ }^{* * *} p<0.01 ;{ }^{* *} p<0.05 ;{ }^{*} p<0.1$.

Models 1-4 corroborate Hypotheses 1 and 2 that suggest opposition parties with extensive organizations and those that disperse decision-making authority among various party members have a lower probability of being co-opted by autocratic incumbents. Model 5

\footnotetext{
${ }^{9}$ Pan-Malaysian Islamic Party (PAS) became a junior coalition partner to the United Malays National Organisation (UMNO) government. But in 1977 party withdrew from the partnership that was widely unpopular among its core supporters. The party has been in the opposition camp since 1977.
} 
introduces control variables such as oil production per capita, GDP per capita, presidential regimes, and the level of electoral democracy. The results lend further support for Hypotheses 1 and 2. The point estimate for organizational extensiveness indicates that, on average, a one-unit increase in organizational extensiveness reduces the probability of co-optation by about 20 percent $(\exp (\beta=-0.22)=0.80)$. Substantively speaking, a change in organizational extensiveness from 20th percentile (-2.22) to 80th percentile (2.92), which is about the difference between Just Russia (SR, Russia) in 2016 and National Action Party (PAN, Mexico) in 1985, reduces the probability of co-optation by around 15 percent. Furthermore, the results suggests that, on average, a one-unit increase in the dispersion of internal decision-making authority reduces the probability of co-optation by around 40 percent $(\exp (\beta=-0.52)=0.60)$. Moving from 20th percentile $(-1.01)$ to 80th percentile (0.82) on the index, which is about the difference between Algerian National Front in 2017 (FNA, Algeria) and New Patriotic Party in 1996 (NPP, Ghana), decreases the probability of co-optation by about 15 percent. Overall, the evidence suggests that opposition parties with extensive organizations and those in which decision-making procedures are dispersed among various party members are significantly less likely to be co-opted.

Models 6 and 7 evaluate Hypotheses 3 and 4 by interacting party organizational features and ideological distance. Given that the magnitude, direction, and statistical significance of the interaction terms as well as their constitutive terms can be misleading and not meaningful (Berry, Golder, \& Milton, 2012), Figure 2A and Figure 2C plot the marginal effects of party organizational features at the full range of the values of ideological distance. In line with Hypothesis 3, Figure 2A demonstrates that with increasing levels of ideological distance, the negative marginal effect of organizational extensiveness on the probability of co-optation becomes stronger. The effect becomes statistically significant when the value of ideological distance surpasses -0.5. The underlying histogram in the plot shows that the statistically significant relationship applies to more than 65 percent of the observations that have an ideological distance score of more than -0.5. Substantively, the coefficient estimate of organizational extensiveness becomes roughly about twice the size of the coefficient in Model 5 for opposition parties with an ideological distance to the incumbent regime similar to that of Tanzania's Party for Democracy and Congress (Chadema) in 2000 or Mexico's 
Party of Democratic Revolution (PRD) in $1994 .{ }^{10}$ In about 35 percent of the observations where opposition parties and the incumbent regime have ideological positions relatively closer to one another, the impact of organizational extensiveness on the probability of co-optation becomes indeterminate.

Figure $2 \mathrm{C}$ plots the marginal effect of the dispersion of internal decision-making authority over the full range of the values of ideological distance. In line with Hypothesis 4, the negative marginal effect of the dispersion of internal decision-making authority becomes stronger as the ideological distance between an opposition party and autocratic incumbents increases. The effect is statistically significant over the values of ideological distance ranging from about -0.78 to 1.01 , which covers 67 percent of the observations. Substantively, however, the effect is only slightly altered as ideological distance increases. The estimated coefficient is about 0.07 point larger than the coefficient in Model 5 for opposition parties that have ideological distance from autocratic incumbents similar to Cameroon's Social Democratic Front (SDF) in 2013, which has a score of 1.01 .

Figure 2B and Figure 2D displays the marginal effect of ideological distance across the range of the values of organizational features. Figure 2B demonstrates that the marginal effect of ideological distance becomes substantially stronger as organizational extensiveness increases. Similarly, Figure 2D indicates stronger negative effect of ideological distance on the probability of co-optation as decision-making procedures within opposition parties become more dispersed. Overall, the observed associations provide evidence in support of Hypotheses 3 and 4 . The effect of organizational features on co-optation is conditional on ideological distance between an opposition party and the incumbent regime. The opposite is also true as indicated by Figure 2B and Figure 2D: the effect of ideological distance is moderated by opposition party organizational features.

\footnotetext{
${ }^{10}$ Chadema in 2000 and PRD in 1994 have ideological distance score of around 1.04.
} 

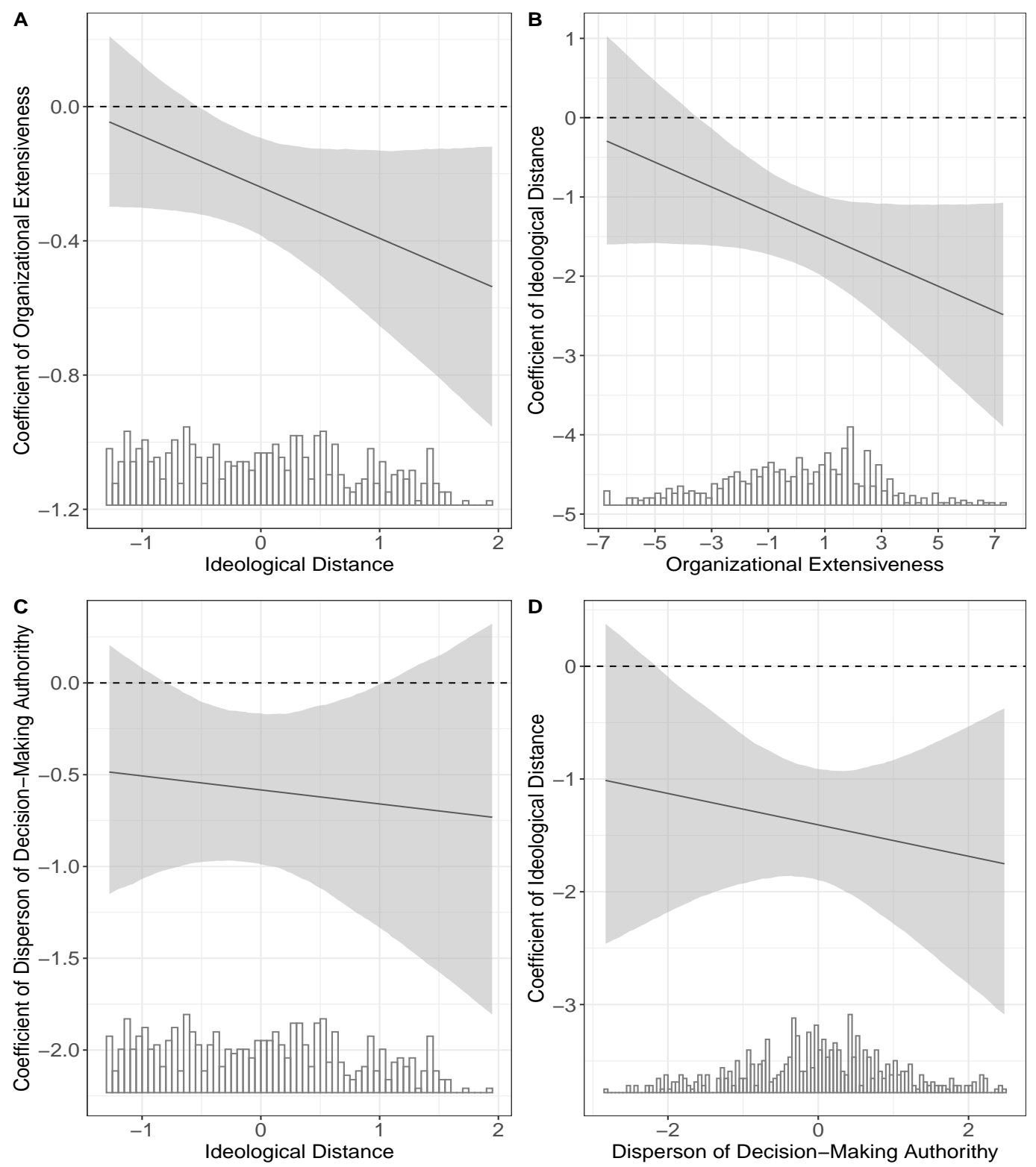

Figure 2: The conditional impact of organizational features and ideological distance on the likelihood of co-optation.

The findings suggest that opposition party co-optation is largely driven by party-level factors. Looking at the country-level factors across Models 5-7, only the level of economic development, proxied by GDP per capita, has a statistically significant relationship with the likelihood of party co-optation. The coefficient for GDP per capita suggests that parties competing in economically less developed electoral autocracies may face greater pressures and incentives to align with autocratic incumbents. Other country-level variables denoting 
oil production per capita, the level of democracy, and weather a country has presidential system or not, have expected coefficient signs, but they do not have statistically significant associations with party co-optation.

\subsection{Robustness Tests}

To assess the robustness of the findings I conduct several additional analyses. First, Appendix Table 2 replicates Models 1-7 by excluding pre-electoral coalitions and an opposition party's declaration of support for incumbents' election bid as co-optation events to further safeguard against the possibility of simultaneity bias. The results in Appendix Table 2 provide further confidence to the main results in that the estimates are substantively similar to those in Table 1.

Second, I control for opposition party seat share and party age (both log transformed), and replicate Models 5-7 in Table 1. Including party seat share allows for testing the relationship between opposition party electoral performance and co-optation, whereas party age should account for the possibility that older parties may be better positioned to coordinate anti-regime collective action (Gandhi \& Reuter, 2013), and thus they may have greater incentive to remain in the opposition camp. It should be noted that party seat share and party age is subject to post-treatment bias because they are to a large extent a function of party organizational features. Nevertheless, controlling for these additional party-level variables do not alter the main findings (see Appendix Table 3).

Third, I control for additional variables related to the broader competitive environment. Specifically, Models 11A-15A in Appendix Table 4 replicates Model 5-7 in Table 1 by controlling for the V-Dem presidentialism index (Coppedge et al., 2020a, 2020b), the extent to which a state owns and controls economic capital (Coppedge et al., 2020a, 2020b), ethnic fractionalization (Alesina, Devleeschauwer, Easterly, Kurlat, \& Wacziarg, 2003), and the seat share of an autocratic ruling party. These controls aim to assess several alternative explanations. First, the V-Dem presidentialism index includes various indicators measuring the constraints on the executive, and thus it allows for testing whether opposition party co-optation is affected by executive constraints. Furthermore, scholars suggest that where opposition parties lack access to independent private capital their capacity to effectively 
coordinate anti-regime collective action decreases (Arriola, 2013; Greene, 2007). Building on this logic, it is possible that in countries where the state controls a sizable share of the economic activity, opposition elites have limited capacity to invest in organizational features and have greater incentives to gain access to economic capital by aligning with incumbents. To account for this explanation, I control for the degree of the state control over the economy. It is also plausible that incumbents may have greater incentives to co-opt opposition parties when they lack parliamentary majority as is the case for the Erdogan regime in Turkey. For this reason, I control for the share of parliamentary seats held by an autocratic ruling party. Controlling for these additional country-level factors do not alter the main findings in Table 1. It is notable that the inclusion of these variables do not improve the model fit, suggesting that these factors do not perform well in explaining party-level co-optation. Finally, the results remain when including regional dummies to ensure the estimates are not affected by the unobserved time-invariant region-specific characteristics (see Model 16A in Appendix Table 4).

Last, the data set includes missing observations (see Appendix Section 1), and missingness can be problematic given the relatively small sample size. To ensure that missingness does not bias the results, I use multiple imputation as described in King, Honaker, Joseph, and Scheve (2001). I impute five data sets using Amelia II package in R, run models in Table 1 on each imputed data set, and then combine the estimates. Table 5 in the appendix presents the results based on the imputed data sets, which are highly similar to Models 1-7 in Table 1.

\section{Conclusion}

Opposition party co-optation is an important survival strategy widely employed by autocratic

incumbents to survive in power. Despite its prevalence, however, little has been done to explain why some opposition parties are co-opted but not others. This article fills this gap by demonstrating that opposition party co-optation is, to a large extent, shaped by the internal features of opposition parties, and the ideological distance between an opposition party and the incumbent regime.

This article demonstrates that organizationally extensive opposition parties, and those 
that distribute internal decision-making authority among various party members, are less likely to be co-opted. Party organizational extensiveness, i.e. nationwide network of active local branches, and entrenched ties to social organizations, boosts opposition party leaders' ability to mobilize against the regime, and survive in autocratic settings, reducing their incentives to make costly compromises on their oppositional stance to the incumbent regime. Moreover, where party leaders face greater internal constraints in bargaining with autocratic incumbents due to dispersed decision-making structures, their ability to make concessions to the regime is significantly hindered, reducing the chances of striking a co-optation agreement with the incumbent regime.

The findings also suggest that as the ideological distance between an opposition party and the incumbent regime increases, the negative impact of these organizational attributes is exacerbated. The costs of establishing a co-optation agreement increases for both autocratic incumbents and opposition party leaders when an opposition party has an extensive organization, dispersed decision-making structures, and ideologically position itself distant from the incumbent regime. Thus, the findings demonstrate that opposition party organizational features and ideological positions substantially shape the ability of autocratic incumbents to co-opt a particular opposition party, regardless of the availability of patronage resources that they can distribute to opposition party leaders, or repressive tactics that they often use to discourage opposition party leaders from maintaining their anti-regime stance.

This is the first cross-national party-level quantitative study of the relationship between internal characteristics of opposition parties, their ideological orientations, and elite cooptation in electoral autocracies. While the findings contribute to the current knowledge about opposition party co-optation (e.g. Arriola et al., 2021; Buckles, 2019; Kelly, 2018), they also promise to further our understanding of the functions and consequences of multiparty elections in autocracies. Recognizing the diversity of opposition party organizational features and their ideological orientations can further the debate on when and why multiparty elections can undermine autocratic regime stability (e.g. Bernhard et al., 2020; Bunce \& Wolchik, 2011; Schedler, 2013). How opposition party characteristics shape the incentives and capabilities of opposition elites to force for a regime change deserves more attention. 


\section{References}

Alesina, A., Devleeschauwer, A., Easterly, W., Kurlat, S., \& Wacziarg, R. (2003). Fractionalization. Journal of Economic growth, 8(2), 155-194.

Arriola, L. (2009). Patronage and political stability in Africa. Comparative Political Studies, 42(10), 1339-1362.

Arriola, L. (2013). Multi-ethnic coalitions in Africa: Business financing of opposition election campaigns. Cambridge University Press.

Arriola, L., DeVaro, J., \& Meng, A. (2021). Democratic subversion: Elite cooptation and opposition fragmentation. In Unpublished manuscript (pp. 1-41).

Bernhard, M., Edgell, A., \& Lindberg, S. I. (2020). Institutionalising electoral uncertainty and authoritarian regime survival. European Journal of Political Research, 59(2), 465487.

Berry, W. D., Golder, M., \& Milton, D. (2012). Improving tests of theories positing interaction. The Journal of Politics, 74 (3), 653-671.

Boix, C., Miller, M., \& Rosato, S. (2013). A complete data set of political regimes, 18002007. Comparative Political Studies, 46(12), 1523-1554.

Bolt, J., \& Van Zanden, J. L. (2014). The maddison project: collaborative research on historical national accounts. The Economic History Review, $67(2)$. Retrieved from https://www.rug.nl/ggdc/historicaldevelopment/ maddison/releases/maddison-project-database-2018?lang=en

Buckles, G. (2019). Internal opposition dynamics and restraints on authoritarian control. British Journal of Political Science, 49(3), 883-900.

Bueno De Mesquita, B., Smith, A., Siverson, R. M., \& Morrow, J. D. (2005). The logic of political survival. MIT press.

Bunce, V. J., \& Wolchik, S. L. (2011). Defeating authoritarian leaders in postcommunist countries. Cambridge University Press.

Clark, T. S., \& Linzer, D. A. (2015). Should I use fixed or random effects. Political Science Research and Methods, 3(2), 399-408.

Conrad, C. R. (2011). Constrained concessions: Beneficent dictatorial responses to the domestic political opposition. International Studies Quarterly, 55(4), 1167-1187.

Coppedge, M., Gerring, J., Knutsen, C. H., Lindberg, S. I., Teorell, J., Altman, D., ... Ziblatt, D. (2020a). V-dem codebook v11.1" varieties of democracy (v-dem) project. Gothenburg: Varieties of Democracy (V-Dem) Project. Retrieved from https://doi . org/10.23696/vdemds20

Coppedge, M., Gerring, J., Knutsen, C. H., Lindberg, S. I., Teorell, J., Altman, D., ... Ziblatt, D. (2020b). V-dem country-year dataset v10. Gothenburg: Varieties of Democracy (V-Dem) Project. Retrieved from https://doi.org/10.23696/vdemds20

Duverger, M. (1959). Political parties, their organization and activity in the modern state. Methuen.

Gandhi, J. (2008). Political institutions under dictatorship. Cambridge University Press.

Gandhi, J., \& Buckles, G. (2016). Opposition unity and cooptation in hybrid regimes. In Annual midwest political science association conference, chicago, il (pp. 1-33).

Gandhi, J., \& Przeworski, A. (2006). Cooperation, cooptation, and rebellion under dictatorships. Economics \& Politics, 18(1), 1-26. 
Gandhi, J., \& Przeworski, A. (2007). Authoritarian institutions and the survival of autocrats. Comparative Political Studies, 40(11), 1279-1301.

Gandhi, J., \& Reuter, O. J. (2013). The incentives for pre-electoral coalitions in nondemocratic elections. Democratization, 20(1), 137-159.

Gel'man, V. (2005). Political opposition in Russia: A dying species? Post-Soviet Affairs, $21(3), 226-246$.

Greene, K. F. (2002). Opposition party strategy and spatial competition in dominant party regimes: A theory and the case of mexico. Comparative Political Studies, 35(7), 755783.

Greene, K. F. (2007). Why dominant parties lose: Mexico's democratization in comparative perspective. Cambridge University Press.

Hyde, S. D., \& Marinov, N. (2012). Which elections can be lost? Political analysis, 20(2), 191-210.

Kelly, C. L. (2018). Party proliferation and trajectories of opposition: Comparative analysis from Senegal. Comparative Politics, 50(2), 209-229.

King, G., Honaker, J., Joseph, A., \& Scheve, K. (2001). Analyzing incomplete political science data: An alternative algorithm for multiple imputation. American Political Science Review, 49-69.

Kitschelt, H. (1994). The transformation of european social democracy. cambridge university press.

LeBas, A. (2014). From protest to parties: Party-building and democratization in africa. Oxford University Press.

Levitsky, S., Loxton, J., Van Dyck, B., \& Domínguez, J. I. (2016). Challenges of partybuilding in Latin America. Cambridge University Press.

Levitsky, S., \& Way, L. A. (2010). Competitive authoritarianism: Hybrid regimes after the cold war. Cambridge University Press.

Lust-Okar, E. (2005). Structuring conflict in the arab world: Incumbents, opponents, and institutions. Cambridge University Press.

Lührmann, A., Düpont, N., Higashijima, M., Kavasoglu, Y. B., Marquardt, K. L., Bernhard, M., ... Seim, B. (2020a). V-Party: Codebook varieties of party identity and organisation (v-party) v1. Gothenburg: Varieties of Democracy (V-Dem) Project. Retrieved from https://www.v-dem.net/en/data/data/v-party-dataset/

Lührmann, A., Düpont, N., Higashijima, M., Kavasoglu, Y. B., Marquardt, K. L., Bernhard, M., ... Seim, B. (2020b). V-Party: The varieties of party identity and organization dataset. Gothenburg: Varieties of Democracy (V-Dem) Project. Retrieved from https://www.v-dem.net/en/data/data/v-party-dataset/

Magaloni, B. (2006). Voting for autocracy: Hegemonic party survival and its demise in Mexico (Vol. 296). Cambridge University Press.

Magaloni, B. (2010). The game of electoral fraud and the ousting of authoritarian rule. American Journal of Political Science, 54(3), 751-765.

Nyrup, J., \& Bramwell, S. (2020). Who governs? a new global dataset on members of cabinets. American Political Science Review, 114(4), 1366-1374.

Panebianco, A. (1988). Political parties: Organization and power. Cambridge University Press.

Rakner, L., \& Van de Walle, N. (2009). Democratization by elections? Opposition weakness 
in Africa. Journal of Democracy, 20(3), 108-121.

Reuter, O. J., \& Robertson, G. B. (2015). Legislatures, cooptation, and social protest in contemporary authoritarian regimes. The Journal of politics, 777(1), 235-248.

Ross, M., \& Mahdavi, P. (2015). Oil and gas data, 1932-2014. Harvard Dataverse, 2. Retrieved from https://dataverse.harvard.edu/dataset. xhtml?persistentId= doi: 10.7910/DVN/ZTPWOY

Samuels, D., \& Shugart, M. S. (2010). Presidents, parties, and prime ministers: How the separation of powers affects party organization and behavior. Cambridge University Press.

Samuels, D., \& Zucco, C. (2015). Crafting mass partisanship at the grass roots. British Journal of Political Science, 45(4), 755-775.

Schedler, A. (2002). The nested game of democratization by elections. International Political Science Review, 23(1), 103-122.

Schedler, A. (2006). Electoral authoritarianism: The dynamics of unfree competition. Lynne Rienner Publishers.

Schedler, A. (2009). The sage handbook of comparative politics.

Schedler, A. (2013). The politics of uncertainty: Sustaining and subverting electoral authoritarianism. Oxford University Press.

Skaaning, S.-E., Gerring, J., \& Bartusevičius, H. (2015). A lexical index of electoral democracy. Comparative Political Studies, 48(12), 1491-1525.

Snijders, T. A., \& Bosker, R. J. (2012). Multilevel analysis: An introduction to basic and advanced multilevel modeling (2nd ed.). Sage Publications Ltd.

Strøm, K. (1994). The presthus debacle: Intraparty politics and bargaining failure in norway. American Political Science Review, 112-127.

Tavits, M. (2013). Post-communist democracies and party organization. Cambridge University Press.

TurkishMinute. (2017). Another former deputy resigns from mhp to join akşener's new party. Turkish Minute. Retrieved from https://www.turkishminute.com/2017/08/ 23/another-former-deputy-resigns-from-mhp-to-join-akseners-new-party/

Van Dyck, B. (2017). The paradox of adversity: The contrasting fates of latin america's new left parties. Comparative Politics, 49(2), 169-192.

Wegner, E. (2011). Islamist opposition in authoritarian regimes: The Party of Justice and Development in Morocco. Syracuse University Press.

Wig, T., Hegre, H., \& Regan, P. M. (2015). Updated data on institutions and elections 1960-2012: presenting the iaep dataset version 2.0. Research $\&$ Politics. 


\section{Supporting Appendix}

\section{Summary statistics}

\begin{tabular}{|c|c|c|c|c|c|c|c|}
\hline Statistic & $\mathrm{N}$ & Mean & St. Dev. & Min & $\operatorname{Pctl}(25)$ & $\operatorname{Pctl}(75)$ & Max \\
\hline Dispersion of intra-party decision-making authority & 604 & -0.360 & 1.025 & -2.727 & -1.020 & 0.270 & 2.835 \\
\hline Number of past co-optation & 604 & 0.439 & 1.260 & 0 & 0 & 0 & 9 \\
\hline Ethnic-regional party & 604 & 0.281 & 0.450 & 0 & 0 & 1 & 1 \\
\hline Religious party & 604 & 0.070 & 0.255 & 0 & 0 & 0 & 1 \\
\hline GPD pc $(\log )$ & 596 & 8.306 & 0.946 & 6.297 & 7.519 & 9.044 & 11.114 \\
\hline Opposition party seat share (log) & 604 & 2.134 & 0.900 & 0.000 & 1.589 & 2.744 & 4.615 \\
\hline Opposition party age (log) & 604 & 2.319 & 1.230 & 0.000 & 1.386 & 3.258 & 4.812 \\
\hline V-Dem presidentialism index & 604 & 0.645 & 0.215 & 0.136 & 0.494 & 0.831 & 0.982 \\
\hline V-Dem state ownerhsip of the economy & 604 & 0.074 & 0.893 & -2.939 & -0.415 & 0.723 & 2.125 \\
\hline Ethnic fractionalization & 604 & 0.517 & 0.239 & 0.002 & 0.339 & 0.710 & 0.930 \\
\hline
\end{tabular}

The data on oil production per capita and GDP per capita are log transformed. Oil production per capita is log transformed after adding 1 to each value to deal with zeros.

I have updated the variable on "the independence of selection of executives" until 2019 in Wig et al. (2015). (Semi) Presidential systems are operationalized as systems in which the executive is elected independently of the legislature. 


\section{List of electoral autocracies (1970 - 2019).}

The sample excludes closed autocracies that do not hold formally competitive elections for the national executive (e.g. China and Saudi Arabia that do not hold multiparty elections, as well as autocracies such as Morocco that only hold formally competitive elections for the legislature), or those that hold elections without full male or full female suffrage (e.g. South Africa until 1994). Elections that are followed by a democratic transition in the subsequent year are excluded from the analysis (e.g. Ghana 2000).

The coding of electoral autocracies involves three steps.

1. First, I use data from Boix, Miller, and Rosato (2013) to establish the sample of autocracies. The data set covers all countries until 2015. I expanded the data set until 2019. The sample additionally covers the following elections: Algeria 2017, Belarus 2016, Belarus 2019, Russia 2016, Djibouti 2018, Uganda 2016, Mozambique 2019, Ivory Coast 2016, Turkey 2018.

2. In the second step, I utilize data from the Lexical Index of Electoral Democracy to select autocracies that hold multiparty elections for both the national executive and the legislature with full male or female suffrage (Skaaning, Gerring, \& Bartusevičius, 2015).

3. Finally, I cross-check the sample of countries with the National Elections Across Democracy and Autocracy Data Set (NELDA), and remove cases where executive elections have no bearing on the selection of de facto leader of the country (e.g. Military regime in Brazil between 1964 and 1985) (Hyde \& Marinov, 2012). 


\begin{tabular}{|c|c|c|c|c|c|}
\hline Country & Election year & Country & Election year & Country & Election year \\
\hline Algeria & 1997 & Kazakhstan & 1994 & Malaysia & 1995 \\
\hline Algeria & 2002 & Kazakhstan & 1995 & Malaysia & 1999 \\
\hline Algeria & 2007 & Kazakhstan & 1999 & Malaysia & 2004 \\
\hline Algeria & 2012 & Kazakhstan & 2004 & Malaysia & 2008 \\
\hline Algeria & 2017 & Kazakhstan & 2012 & Malaysia & 2013 \\
\hline Angola & 1992 & Kyrgyzstan & 1995 & Paraguay & 1973 \\
\hline Angola & 2008 & Kyrgyzstan & 2000 & Paraguay & 1978 \\
\hline Angola & 2012 & Kyrgyzstan & 2007 & Paraguay & 1983 \\
\hline Angola & 2017 & Kyrgyzstan & 2010 & Paraguay & 1988 \\
\hline Armenia & 1995 & Kyrgyzstan & 2015 & Paraguay & 1989 \\
\hline Armenia & 1999 & Madagascar & 1970 & Paraguay & 1993 \\
\hline Armenia & 2003 & Madagascar & 1977 & Paraguay & 1998 \\
\hline Armenia & 2007 & Madagascar & 1983 & Serbia & 1992 \\
\hline Armenia & 2012 & Madagascar & 1989 & Serbia & 1993 \\
\hline Azerbaijan & 1995 & Madagascar & 2013 & Serbia & 1997 \\
\hline Azerbaijan & 2000 & Namibia & 1994 & Singapore & 1972 \\
\hline Azerbaijan & 2005 & Namibia & 1999 & Singapore & 1976 \\
\hline Belarus & 1995 & Namibia & 2004 & Singapore & 1980 \\
\hline Belarus & 2000 & Namibia & 2009 & Singapore & 1984 \\
\hline Belarus & 2004 & Namibia & 2014 & Singapore & 1988 \\
\hline Belarus & 2008 & Rwanda & 2003 & Singapore & 1991 \\
\hline Belarus & 2016 & Rwanda & 2008 & Singapore & 1997 \\
\hline Belarus & 2019 & Rwanda & 2013 & Singapore & 2001 \\
\hline Cameroon & 1992 & Egypt & 1976 & Singapore & 2006 \\
\hline Cameroon & 1997 & Egypt & 1979 & Singapore & 2011 \\
\hline Cameroon & 2002 & Egypt & 1984 & Singapore & 2015 \\
\hline Cameroon & 2007 & Egypt & 1987 & El Salvador & 1970 \\
\hline Cameroon & 2013 & Egypt & 2011 & El Salvador & 1972 \\
\hline Russia & 1999 & Egypt & 2015 & El Salvador & 1974 \\
\hline Russia & 2003 & Sri Lanka & 1977 & El Salvador & 1978 \\
\hline Russia & 2007 & Sri Lanka & 1989 & Bangladesh & 1979 \\
\hline Russia & 2011 & Sri Lanka & 2010 & Bangladesh & 1986 \\
\hline Russia & 2016 & Sri Lanka & 2015 & Bangladesh & 1988 \\
\hline Democratic Republic of the Congo & 2006 & Tajikistan & 1995 & Bangladesh & 2008 \\
\hline Democratic Republic of the Congo & 2011 & Tajikistan & 2000 & Bangladesh & 2014 \\
\hline Djibouti & 1992 & Tajikistan & 2005 & Haiti & 2006 \\
\hline Djibouti & 1997 & Tajikistan & 2015 & Haiti & 2010 \\
\hline Djibouti & 2003 & Togo & 1994 & Haiti & 2015 \\
\hline Djibouti & 2013 & Togo & 2007 & Mali & 2013 \\
\hline Djibouti & 2018 & Togo & 2013 & Mexico & 1970 \\
\hline Gabon & 1990 & Turkmenistan & 2013 & Mexico & 1973 \\
\hline Gabon & 1996 & Uzbekistan & 1999 & Mexico & 1976 \\
\hline Gabon & 2001 & Uzbekistan & 2004 & Mexico & 1979 \\
\hline Gabon & 2006 & Uzbekistan & 2009 & Mexico & 1982 \\
\hline Gambia & 1997 & Uzbekistan & 2014 & Mexico & 1985 \\
\hline Gambia & 2002 & Croatia & 1992 & Mexico & 1988 \\
\hline Gambia & 2007 & Croatia & 1995 & Mexico & 1991 \\
\hline Gambia & 2012 & Equatorial Guinea & 1993 & Mexico & 1994 \\
\hline Georgia & 1992 & Equatorial Guinea & 1999 & Mexico & 1997 \\
\hline Georgia & 1995 & Equatorial Guinea & 2004 & Peru & 1990 \\
\hline Georgia & 1999 & Equatorial Guinea & 2008 & Peru & 1995 \\
\hline Georgia & 2003 & Equatorial Guinea & 2013 & Senegal & 1978 \\
\hline Guinea-Bissau & 1999 & Guyana & 1973 & Senegal & 1983 \\
\hline Guinea-Bissau & 2004 & Guyana & 1980 & Senegal & 1988 \\
\hline Guinea-Bissau & 2008 & Guyana & 1985 & Senegal & 1993 \\
\hline Guinea-Bissau & 2014 & Malaysia & 1974 & Senegal & 1998 \\
\hline Albania & 1991 & Malaysia & 1978 & Ethiopia & 2005 \\
\hline Albania & 1992 & Malaysia & 1982 & Kenya & 1992 \\
\hline Albania & 1996 & Malaysia & 1986 & Kenya & 1997 \\
\hline Albania & 1997 & Malaysia & 1990 & South Korea & 1971 \\
\hline
\end{tabular}




\begin{tabular}{|c|c|c|c|}
\hline Country & Election year & Country & Election year \\
\hline South Korea & 1973 & Ivory Coast & 1995 \\
\hline South Korea & 1978 & Ivory Coast & 2000 \\
\hline South Korea & 1981 & Ivory Coast & 2001 \\
\hline South Korea & 1985 & Ivory Coast & 2011 \\
\hline Nigeria & 1999 & Ivory Coast & 2016 \\
\hline Nigeria & 2003 & Mauritania & 1992 \\
\hline Nigeria & 2007 & Mauritania & 2001 \\
\hline Nigeria & 2011 & Mauritania & 2006 \\
\hline Philippines & 1978 & Mauritania & 2013 \\
\hline Philippines & 1984 & Ghana & 1992 \\
\hline Tanzania & 1995 & Ghana & 1996 \\
\hline Tanzania & 2000 & Central African Republic & 2005 \\
\hline Tanzania & 2005 & Central African Republic & 2011 \\
\hline Tanzania & 2010 & Lesotho & 1993 \\
\hline Tanzania & 2015 & Lesotho & 1998 \\
\hline Taiwan & 1995 & Panama & 1980 \\
\hline Uganda & 2006 & Panama & 1984 \\
\hline Uganda & 2011 & Panama & 1989 \\
\hline Uganda & 2016 & Sierra Leone & 1977 \\
\hline Venezuela & 2005 & Sierra Leone & 1996 \\
\hline Venezuela & 2010 & Turkey & 2015 \\
\hline Venezuela & 2015 & Turkey & 2018 \\
\hline Burkina Faso & 1970 & & \\
\hline Burkina Faso & 1978 & & \\
\hline Burkina Faso & 1992 & & \\
\hline Burkina Faso & 1997 & & \\
\hline Burkina Faso & 2002 & & \\
\hline Burkina Faso & 2007 & & \\
\hline Burkina Faso & 2012 & & \\
\hline Burkina Faso & 2015 & & \\
\hline Cambodia & 1998 & & \\
\hline Cambodia & 2003 & & \\
\hline Cambodia & 2008 & & \\
\hline Cambodia & 2013 & & \\
\hline Mozambique & 1999 & & \\
\hline Mozambique & 2004 & & \\
\hline Mozambique & 2009 & & \\
\hline Mozambique & 2014 & & \\
\hline Mozambique & 2019 & & \\
\hline Nicaragua & 1972 & & \\
\hline Nicaragua & 1974 & & \\
\hline Niger & 1996 & & \\
\hline Niger & 2009 & & \\
\hline Zambia & 1991 & & \\
\hline Zambia & 1996 & & \\
\hline Zambia & 2001 & & \\
\hline Zambia & 2006 & & \\
\hline Zimbabwe & 1990 & & \\
\hline Zimbabwe & 1995 & & \\
\hline Zimbabwe & 2000 & & \\
\hline Zimbabwe & 2005 & & \\
\hline Zimbabwe & 2008 & & \\
\hline Zimbabwe & 2013 & & \\
\hline Guinea & 1995 & & \\
\hline Guinea & 2002 & & \\
\hline Guinea & 2013 & & \\
\hline Guinea & 1995 & & \\
\hline Guinea & 2002 & & \\
\hline Guinea & 2013 & & \\
\hline Ivory Coast & 1990 & & \\
\hline
\end{tabular}




\section{Coding opposition party co-optation}

A party is coded as co-opted at a party-election-year if any of the following four conditions is observed in subsequent years until the next party-election-year. Information on the four criteria was collected using several sources.

1. Opposition party joins a pre-electoral coalition led by the autocratic incumbent. Source: V-Party Data Set variable, v2paallian (Lührmann et al., 2020a). In addition, Political Handbook of the World series (1975 - 2019).

2. Opposition party declares its support to the incumbent's election bid without building a formal electoral alliance with the incumbent.

Source: Political Handbook of the World series (1975 - 2019).

3. Opposition party provides parliamentary support to the incumbent government. Source: V-Party Data Set variable, v2pagovsup (Lührmann et al., 2020a). In addition, Political Handbook of the World series (1975 - 2019).

4. Opposition party member is appointed to the cabinet.

Source: Cabinet data from Nyrup and Bramwell (2020).

V-Party survey asks experts to code whether the party supports and/or is part of the government formed immediately after an election. In presidential systems where the elections for the executive and legislative branches of government are non-concurrent, the measure informs us about whether the party supports the existing government.

Variable: v2pagovsup (Lührmann et al., 2020a).

Expert survey question:

Question: Does this party support the government formed immediately after this election? Responses:

0: Yes, as senior partner. The Head of Government belongs to this party.

1: Yes, as junior partner. The Head of Government does not belong to this party, but one or more cabinet ministers do.

2: Yes, but the party is not officially represented in government.

3: No, party is in opposition to the government.

4: Not applicable. No government took office based on this election (yet). (In autocracies, this response option typically corresponds to the cases where elections were annulled.)

Variable: v2paallian (Lührmann et al., 2020a).

Was the party part of a temporary pre-electoral alliance in this national election or is the entity actually an alliance?

Responses:

0: No.

1: Yes, party was part of an alliance.

2: Yes, entity is an alliance of two or more parties. 
If the party was part of an alliance, I identified whether the alliance is led by the autocratic ruling party using the V-Party variable, v2panaallian, which includes information on the names of pre-electoral alliances, and checked for the parties included in the alliance. 


\section{Opposition Party Co-optation (1970 - 2019).}

\begin{tabular}{|c|c|c|}
\hline Country & Party & Election Year \\
\hline Albania & Republican Party of Albania & 1996 \\
\hline Albania & Albanian National Front Party & 1996 \\
\hline Albania & Social Democratic Party of Albania & 1997 \\
\hline Algeria & Movement for the Society of Peace & 1997 \\
\hline Algeria & Movement of the Islamic Renaissance & 1997 \\
\hline Algeria & Movement for the Society of Peace & 2002 \\
\hline Algeria & Movement for National Reform & 2002 \\
\hline Algeria & Movement for the Society of Peace & 2007 \\
\hline Algeria & Movement for National Reform & 2012 \\
\hline Algeria & Movement of the Islamic Renaissance & 2012 \\
\hline Algeria & Algerian National Front & 2017 \\
\hline Armenia & Armenian Revolutionary Federation & 1999 \\
\hline Armenia & National Democratic Union & 1999 \\
\hline Armenia & Rule of Law / Armenian Renaissance & 2003 \\
\hline Armenia & Armenian Revolutionary Federation & 2003 \\
\hline Armenia & Armenian Revolutionary Federation & 2007 \\
\hline Armenia & Prosperous Armenia Party & 2007 \\
\hline Armenia & Rule of Law / Armenian Renaissance & 2007 \\
\hline Armenia & Prosperous Armenia Party & 2012 \\
\hline Armenia & Rule of Law / Armenian Renaissance & 2012 \\
\hline Azerbaijan & Azerbaijan National Independence Party & 1995 \\
\hline Bangladesh & Bangladesh Muslim League & 1979 \\
\hline Bangladesh & National Party (Ershad) & 2008 \\
\hline Bangladesh & National Party (Ershad) & 2014 \\
\hline Belarus & Agrarian Party & 1995 \\
\hline Belarus & Agrarian Party & 2000 \\
\hline Belarus & Communist Party of Belarus & 2016 \\
\hline Belarus & Liberal Democratic Party & 2019 \\
\hline Burkina Faso & African Regroupment Party & 1978 \\
\hline Burkina Faso & National Convention of Progressive Patriots-Social Democratic Party & 1992 \\
\hline Burkina Faso & Alliance for Democracy and Federation & 1992 \\
\hline Burkina Faso & Alliance for Democracy and Federation & 1997 \\
\hline Burkina Faso & Alliance for Democracy and Federation-African Democratic Rally & 2002 \\
\hline Burkina Faso & Alliance for Democracy and Federation-African Democratic Rally & 2007 \\
\hline Burkina Faso & Alliance for Democracy and Federation-African Democratic Rally & 2012 \\
\hline Cambodia & National United Front for an Independent, Neutral, Peaceful, and Cooperative Cambodia & 1998 \\
\hline Cambodia & National United Front for an Independent, Neutral, Peaceful, and Cooperative Cambodia & 2003 \\
\hline Cambodia & National United Front for an Independent, Neutral, Peaceful, and Cooperative Cambodia & 2008 \\
\hline Cambodia & Norodom Ranariddh Party & 2008 \\
\hline Cameroon & Union of the Peoples of Cameroon & 1992 \\
\hline Cameroon & National Union for Democracy and Progress & 1997 \\
\hline Central African Republic & Action Party for Development & 2011 \\
\hline Central African Republic & Movement for Democracy and Development & 2011 \\
\hline Democratic Republic of the Congo & Movement for the Liberation of the Congo & 2006 \\
\hline Democratic Republic of the Congo & Forces for Renewal & 2006 \\
\hline Democratic Republic of the Congo & Unified Lumumbist Party & 2006 \\
\hline Democratic Republic of the Congo & Social Movement for Renewal & 2006 \\
\hline Democratic Republic of the Congo & People's Party for Peace and Democracy & 2011 \\
\hline Democratic Republic of the Congo & Movement for the Liberation of the Congo & 2011 \\
\hline Democratic Republic of the Congo & Social Movement for Renewal & 2011 \\
\hline Democratic Republic of the Congo & Union for the Congolese Nation & 2011 \\
\hline Djibouti & Movement for Democratic Renewal and Development / Party for Democratic Renewal & 1992 \\
\hline Djibouti & Front for the Restoration of Unity and Democracy & 1997 \\
\hline Djibouti & Movement for Democratic Renewal and Development / Party for Democratic Renewal & 1997 \\
\hline Egypt & Liberal Socialists Party & 1976 \\
\hline Egypt & Liberal Socialists Party & 1987 \\
\hline Egypt & Free Egyptians Party & 2011 \\
\hline Egypt & New Wafd Party & 2015 \\
\hline Egypt & Free Egyptians Party & 2015 \\
\hline Egypt & Nation's Future Party & 2015 \\
\hline Equatorial Guinea & Liberal Party & 1993 \\
\hline Equatorial Guinea & Social Democratic Union & 1993 \\
\hline Gabon & Gabonese Progress Party & 1990 \\
\hline Gabon & National Regeneration Movement & 1990 \\
\hline Gabon & National Woodcutters (Lumberjacks) Rally - Rally for Gabon & 1996 \\
\hline Gabon & Gabonese Progress Party & 1996 \\
\hline Gabon & National Woodcutters (Lumberjacks) Rally - Rally for Gabon & 2001 \\
\hline Gabon & National Woodcutters (Lumberjacks) Rally - Rally for Gabon & 2006 \\
\hline Gabon & Union of the Gabonese People & 2006 \\
\hline Georgia & National Democratic Party of Georgia & 1992 \\
\hline Georgia & Democratic Party & 1992 \\
\hline Georgia & Unity Bloc & 1992 \\
\hline Georgia & Union for the Democratic Revival & 1995 \\
\hline Georgia & National Democratic Party of Georgia & 1995 \\
\hline Georgia & Union for the Democratic Revival & 1999 \\
\hline Georgia & Industry will save Georgia & 1999 \\
\hline Georgia & New Rights & 2003 \\
\hline Georgia & Union for the Democratic Revival & 2003 \\
\hline Ghana & National Convention Party & 1992 \\
\hline Guinea & Union for Progress and Renewal & 2002 \\
\hline Guinea-Bissau & Resistance of Guinea-Bissau-Bafatá Movement & 1999 \\
\hline Guinea-Bissau & United Social Democratic Party & 2004 \\
\hline Guinea-Bissau & Social Renewal Party & 2004 \\
\hline Guinea-Bissau & Social Renewal Party & 2008 \\
\hline Guinea-Bissau & Republican Party for Independence and Development & 2008 \\
\hline Haiti & Democratic Alliance Party & 2006 \\
\hline
\end{tabular}


Haiti

Hait

Hait

Hait

Hait

Hait

Hait

Ivory Coast

Kazakhstan

Kazakhstan

Kazakhstan

Kazakhstan

Kazakhstan

Kazakhstan

Kazakhstan

Kazakhstan

Kazakhstan

Kyrgyzstan

Kyrgyzstan

Kyrgyzstan

Kyrgyzstan

Kyrgyzstan

Kyrgyzstan

Kyrgyzstan

Kyrgyzstan

Kyrgyzstan

Kyrgyzstan

Kyrgyzstan

Kyrgyzstan

Kyrgyzstan

Kyrgyzstan

Kyrgyzstan

Kyrgyzstan

Madagascar

Madagascar

Madagascar

Madagascar

Madagascar

Madagascar

Malaysia

Malaysia

Malaysia

Malaysia

Malaysia

Malaysia

Malaysia

Malaysi:

Malaysia

Malaysia

Malaysia

Malaysia

Malaysia

Malaysia

Malaysia

Malaysi.

Malaysia

Malaysia

Malaysia

Malaysia

Malaysia

Malaysia

Malaysia

Malaysia

Malaysia

Malaysia

Malaysia

Malaysia

Malaysia

Malaysia

Malaysia

Malaysia

Malaysia

Malaysia

Malaysia

Malaysia

Malaysia

Malaysia

Malaysia

Malaysia

Mali

Mauritania

Mauritania

Mauritania

Mauritania

Mauritania

Mauritania

Mauritania

Niger

Nige

Niger

Niger
Lavalas Political Organization / Struggling People's Organization 2006

Fusion of Haitian Social Democrats 2006

2010

Together We Are Strong $\quad 2010$

$\begin{array}{ll}\text { Lanvi Organisation } & 2010\end{array}$

Haiti in Action

Democratic Party of Côte d'Ivoire - African Democratic Rally

Federation of Trade Unions of the Republic of Kazakhstan

Democratic Party

Federation of Trade Unions of the Republic of Kazakhstan

Agrarian Party of Kazakhstan

Civic Party of Kazakhstan

Agrarian Party of Kazakhstan

All Together

Democratic Party of Kazakhstan Bright Path

Democratic Party of Kazakhstan Bright Path

Communist People's Party of Kazakhstan

Social Democratic Party Kyrgystan

Party of Communists of Kyrgyzstan

My Country Party of Action

Democratic Women's Party of Kyrgyzstan

Political Party of Afghan War Veterans

Union of Democratic Forces

Social Democratic Party Kyrgystan

Party of Communists of Kyrgyzstan

Socialist Party 'Fatherland'

Dignity

Respublika

Ata Zhurt / Fatherland

Socialist Party 'Fatherland'

Önügüü-Progress

Bir Bol

Kyrgyzstan Party

Popular Impulse for National Unity

Congress Party for the Independence of Madagascar

Party for Proletarian Power / Movement for the Progress of Madagascar

Congress Party for the Independence of Madagascar 1983

Congress Party for the Independence of Madagascar 1989

$\begin{array}{lr}\text { Political-based groups working together } & 2013 \\ \text { Malaysian Indian Congress } & 1974\end{array}$

Malaysian Chinese Association

United Bumiputera Heritage Party

Sarawak National Party

Pan-Malaysian Islamic Party

United Sabah National Organisation

Malaysian Chinese Association

Sabah People's United Front

United Bumiputera Heritage Party

Sarawak National Party

Malaysian Indian Congress

United Bumiputera Heritage Party

Malaysian Indian Congress

Malaysian Chinese Association

Sabah People's United Front

United Sabah Party

Malaysian Chinese Association

Malaysian Indian Congress

United Bumiputera Heritage Party

United Bumiputera Heritage Party

United Sabah Party

Malaysian Chinese Association

Malaysian Indian Congress

Malaysian Indian Congres

United Sabah Party

Malaysian Chinese Association

United Bumiputera Heritage Party

United Bumiputera Heritage Party

Malaysian Chinese Association

United Sabah Party

Malaysian Indian Congress

Malaysian Indian Congres

Malaysian Chinese Association

United Bumiputera Heritage Party

United Bumiputera Heritage Party

Malaysian Chinese Association

Malaysian Indian Congress

United Bumiputera Heritage Party

Malaysian Chinese Association

Malaysian Indian Congress

2013

The Alliance for Democracy in Mali - Pan-African Party for Liberty, Solidarity and Justice 2013

Rally for Democracy and Unity

Union for Democracy and Progress

Rally for Democracy and Unity

Union of the Forces of Progres

People's Progressive Alliance

Party of the Democratic and Social Agreement

National Rally for Reform and Development

Party for People's Dignity

Nigerien Alliance for Democracy and Progress

Social Democratic Rally

Rally for Democracy and Progress / National Union of Independents for Democratic Renewal 


\begin{tabular}{|c|c|c|}
\hline Nigeria & All Nigeria People's Party & 1999 \\
\hline Panama & National Liberal Party & 1980 \\
\hline Panama & Liberal Party & 1984 \\
\hline Panama & Republican Party & 1984 \\
\hline Panama & Labor and Agrarian Party & 1984 \\
\hline Panama & Labor and Agrarian Party & 1989 \\
\hline Russia & Liberal Democratic Party of Russia & 1999 \\
\hline Russia & Union of Right Forces & 1999 \\
\hline Russia & Fatherland - All Russia & 1999 \\
\hline Russia & Russian United Democratic Party " "Yabloko" " & 1999 \\
\hline Russia & Motherland - National Patriotic Union & 2003 \\
\hline Russia & Liberal Democratic Party of Russia & 2003 \\
\hline Russia & Liberal Democratic Party of Russia & 2007 \\
\hline Russia & Just Russia & 2007 \\
\hline Russia & Liberal Democratic Party of Russia & 2011 \\
\hline Russia & Just Russia & 2011 \\
\hline Russia & Just Russia & 2016 \\
\hline Russia & Liberal Democratic Party of Russia & 2016 \\
\hline Rwanda & Liberal Party & 2003 \\
\hline Rwanda & Social Democratic Party & 2003 \\
\hline Rwanda & Social Democratic Party & 2008 \\
\hline Rwanda & Liberal Party & 2008 \\
\hline Rwanda & Liberal Party & 2013 \\
\hline Rwanda & Social Democratic Party & 2013 \\
\hline Senegal & Senegalese Democratic Party & 1988 \\
\hline Senegal & Senegalese Democratic Party & 1993 \\
\hline Serbia & Serbian Radical Party & 1992 \\
\hline Serbia & Serbian Radical Party & 1997 \\
\hline Sierra Leone & Sierra Leone People's Party & 1977 \\
\hline Sierra Leone & People's Democratic Party & 1996 \\
\hline Sierra Leone & National Unity Party & 1996 \\
\hline Sri Lanka & Ceylon Workers' Congress & 1989 \\
\hline Sri Lanka & Lanka Equal Society Party & 2010 \\
\hline Sri Lanka & Communist Party of Sri Lanka & 2010 \\
\hline Sri Lanka & Ceylon Workers' Congress & 2010 \\
\hline Sri Lanka & Ceylon Workers' Congress & 2015 \\
\hline Tajikistan & Communist Party of Tajikistan & 1995 \\
\hline Tajikistan & Communist Party of Tajikistan & 2000 \\
\hline Tajikistan & Communist Party of Tajikistan & 2005 \\
\hline Tajikistan & Agrarian Party & 2015 \\
\hline Togo & Action Committee for Renewal & 2007 \\
\hline Togo & Union of Forces for Change & 2013 \\
\hline Turkey & Nationalist Movement [Action] Party & 2015 \\
\hline Turkmenistan & Party of Industrialists and Entrepreneurs & 2013 \\
\hline Turkmenistan & Women's Union of Turkmenistan & 2013 \\
\hline Uganda & Forum for Democratic Change & 2006 \\
\hline Uganda & Forum for Democratic Change & 2011 \\
\hline Uganda & Forum for Democratic Change & 2016 \\
\hline Uzbekistan & Progress Party of the Fatherland & 1999 \\
\hline Uzbekistan & People's Democratic Party of Uzbekistan & 1999 \\
\hline Uzbekistan & People's Democratic Party of Uzbekistan & 2004 \\
\hline Uzbekistan & Uzbekistan National Revival Democratic Party & 2004 \\
\hline Uzbekistan & Self-Sacrifice National Democratic Party & 2004 \\
\hline Uzbekistan & People's Democratic Party of Uzbekistan & 2009 \\
\hline Uzbekistan & Uzbekistan National Revival Democratic Party & 2009 \\
\hline Uzbekistan & People's Democratic Party of Uzbekistan & 2014 \\
\hline Uzbekistan & Justice Social Democratic Party & 2014 \\
\hline Uzbekistan & Uzbekistan National Revival Democratic Party & 2014 \\
\hline Uzbekistan & Ecological Movement of Uzbekistan & 2014 \\
\hline Venezuela & For Social Democracy & 2005 \\
\hline Venezuela & Fatherland for All & 2005 \\
\hline Venezuela & Fatherland for All & 2010 \\
\hline Zimbabwe & Movement for Democratic Change - Ncube & 2008 \\
\hline Zimbabwe & Movement for Democratic Change - Tsvangirai & 2008 \\
\hline
\end{tabular}




\section{Varieties of Party Identity and Organization (V-Party) expert survey questions}

The expert survey is developed in a series of consultative meetings between 2017 and 2019 and tested in a pilot study in summer 2019. V-Party recruited around 665 country experts to conduct the coding in January 2020. All expert responses were collected by the end of April 2020. Each party-election-year observation is typically coded by at least 4 experts who are specialized in party research. Experts respond to survey questions on ordinal five-point likert scales. The V-Dem measurement model, a custom-made Baysesian item response theory model, is used to convert expert responses from ordinal scores into interval scores that capture the values of the observed latent phenomenon.

\section{Local party branches (v2palocoff)}

Question: Does this party maintain permanent offices that operate outside of election campaigns at the local or municipal-level?

Clarification: By "local or municipal" we mean low level administrative divisions that are ranked below regions, provinces, or states. We refer to offices that maintain professional personnel and continued interaction of the party with citizens. Permanent offices operate outside of election campaigns.

Responses:

0: The party does not have permanent local offices.

1: The party has permanent local offices in few municipalities.

2: The party has permanent local offices in some municipalities.

3: The party has permanent local offices in most municipalities.

4: The party has permanent local offices in all or almost all municipalities.

Cross-coder aggregation: Bayesian item response theory measurement model.

\section{Local Active Presence (v2paactcom)}

Question: To what degree are party activists and personnel permanently active in local communities?

Clarification: Please consider the degree to which party activists and personnel are active both during election and non-election periods. Party personnel refers to paid staff.

Responses:

0: There is negligible permanent presence of party activists and personnel in local communities.

1: There is minor permanent presence of party activists and personnel in local communities.

2: There is noticeable permanent presence of party activists and personnel in local communities.

3: There is significant permanent presence of party activists and personnel in local communities. 
4: There is widespread permanent presence of party activists and personnel in local communities.

Cross-coder aggregation: Bayesian item response theory measurement model.

\section{Affiliate organizations (v2pasoctie)}

Question: To what extent does this party maintain ties to prominent social organizations?

Clarification: When evaluating the strength of ties between the party and social organizations please consider the degree to which social organizations contribute to party operations by providing material and personnel resources, propagating the party's message to its members and beyond, as well as by directly participating in the party's electoral campaign and/or mobilization efforts. Social organizations include: Religious organizations (e.g. churches, sects, charities), trade unions/syndical organizations or cooperatives, cultural and social associations (e.g. sports clubs, neighborhood associations), political associations (e.g. environmental protection) and professional and business associations. Social organizations do not include paramilitary units or militias.

Responses:

0: The party does not maintain ties to any prominent social organization.

1: The party maintains weak ties to prominent social organizations.

2: The party maintains moderate ties to prominent social organizations.

3: The party maintains strong ties to prominent social organizations.

4: The party controls prominent social organizations.

Cross-coder aggregation: Bayesian item response theory measurement model.

\section{Candidate nomination (v2panom)}

Question: Which of the following options best describes the process by which the party decides on candidates for the national legislative elections?

Clarification: If nomination procedures vary across constituencies consider the most common practice.

Responses:

0: The party leader unilaterally decides on which candidates will run for the party in national legislative elections.

1: The national party leadership (i.e. an executive committee) collectively decides which candidates will run for the party in national legislative elections.

2: Delegates of local/regional organizations decide which candidates will run for the party in national legislative elections.

3: All party members decide on which candidates will run for the party in national legislative elections in primaries/caucuses.

4: All registered voters decide on which candidates will run for the party in national legislative elections in primaries/caucuses.

Cross-coder aggregation: Bayesian item response theory measurement model. 
5. Personalization of party (v2paind) - This variable is reversed to construct the index.

Question: To what extent is this party a vehicle for the personal will and priorities of one individual leader?

Responses:

0: The party is not focused on the personal will and priorities of one individual leader.

1: The party is occasionally focused on the personal will and priorities of one individual party leader.

2: The party is somewhat focused on the personal will and priorities of one individual party leader.

3: The party is mainly focused on the personal will and priorities of one individual party leader.

4: The party is solely focused on the personal will and priorities of one individual party leader.

Cross-coder aggregation: Bayesian item response theory measurement model

6. Party support group (v2pagroup) (Options 5 and 12 were merged to construct the dummy variable indicating ethnic-regional parties. A party is considered to ethnicregional or religious if more than half of the experts selected the relevant categories.)

Question: To which particular group in society does the core membership and supporters of this party belong?

Clarification: Choose only the key groups. Though you may choose up to three groups, if only one group is most relevant, please only choose that group.

Responses:

0 : No specific, clearly identifiable group. $(0=\mathrm{No}, 1=\mathrm{Yes})$

1: The aristocracy, including high status hereditary social groups and castes. $(0=\mathrm{No}$, $1=$ Yes)

2: Agrarian elites, including rich peasants and large landholders. $(0=\mathrm{No}, 1=\mathrm{Yes})$

3: Business elites. $(0=\mathrm{No}, 1=\mathrm{Yes})$

4: The military. $(0=\mathrm{No}, 1=$ Yes $)$

5: An ethnic or racial group $(\mathrm{s}) .(0=\mathrm{No}, 1=\mathrm{Yes})$

6: A religious $\operatorname{group}(\mathrm{s}) \cdot(0=\mathrm{No}, 1=\mathrm{Yes})$

7: Local elites, including customary chiefs. $(0=\mathrm{No}, 1=\mathrm{Yes})$

8: Urban working classes, including labor unions. $(0=\mathrm{No}, 1=\mathrm{Yes})$

9: Urban middle classes. $(0=\mathrm{No}, 1=\mathrm{Yes})$

10: Rural working classes (e.g. peasants). $(0=\mathrm{No}, 1=\mathrm{Yes})$

11: Rural middle classes (e.g., family farmers). ( $0=\mathrm{No}, 1=\mathrm{Yes})$

12: Regional groups or separatists. $(0=\mathrm{No}, 1=\mathrm{Yes})$

13: Women. $(0=$ No, $1=$ Yes $)$

14: Other specific groups. $(0=\mathrm{No}, 1=\mathrm{Yes})$

\section{Political pluralism (v2paplur)}


Question: Prior to this election, to what extent was the leadership of this political party clearly committed to free and fair elections with multiple parties, freedom of speech, media, assembly and association?

Clarification: Party leaders show no commitment to such principles if they openly support an autocratic form of government without elections or freedom of speech, assembly and association (e.g. theocracy; single-party rule; revolutionary regime). Party leaders show a full commitment to key democratic principles if they unambiguously support freedom of speech, media, assembly and association and pledge to accept defeat in free and fair elections.

Responses:

0: Not at all committed. The party leadership was not at all committed to free and fair, multi-party elections, freedom of speech, media, assembly and association.

1: Not committed. The party leadership was not committed to free and fair, multiparty elections, freedom of speech, media, assembly and association.

2: Weakly committed. The party leadership was weakly committed to free and fair, multiparty elections, freedom of speech, media, assembly and association.

3: Committed. The party leadership was committed to free and fair, multi-party elections, freedom of speech, media, assembly and association.

4: Fully committed. The party leadership was fully committed to free and fair, multiparty elections, freedom of speech, media, assembly and association.

Cross-coder aggregation: Bayesian item response theory measurement model.

8. Economic left-right scale (v2pariglef) Question: Please locate the party in terms of its overall ideological stance on economic issues.

Clarification: Parties on the economic left want government to play an active role in the economy. This includes higher taxes, more regulation and government spending and a more generous welfare state. Parties on the economic right emphasize a reduced economic role for government: privatization, lower taxes, less regulation, less government spending, and a leaner welfare state.

Responses:

0: Far-left.

1: Left.

2: Center-left.

3: Center.

4: Center-right.

5: Right.

6: Far-right.

Cross-coder aggregation: Bayesian item response theory measurement model. 
Table 1: Correlation Matrix of Organizational Features and Ideological Orientations

\begin{tabular}{|c|c|c|c|c|c|c|c|}
\hline & v2palocoff & v2paactcom & v2pasoctie & v2panom & $\begin{array}{c}\text { v2paind } \\
\text { (not reversed) }\end{array}$ & $\begin{array}{l}\text { v2paplur } \\
\text { (distance) }\end{array}$ & $\begin{array}{l}\text { v2pariglef } \\
\text { (distance) }\end{array}$ \\
\hline v2palocoff & 1.00 & 0.74 & 0.55 & 0.22 & -0.00 & -0.04 & -0.05 \\
\hline v2paactcom & 0.74 & 1.00 & 0.67 & 0.34 & -0.00 & 0.09 & 0.14 \\
\hline v2pasoctie & 0.55 & 0.67 & 1.00 & 0.22 & -0.12 & 0.07 & 0.02 \\
\hline v2panom & 0.22 & 0.34 & 0.22 & 1.00 & -0.44 & 0.28 & 0.14 \\
\hline v2paind (not reversed) & -0.00 & -0.00 & -0.12 & -0.44 & 1.00 & -0.05 & -0.10 \\
\hline v2paplur (distance) & -0.04 & 0.09 & 0.07 & 0.28 & -0.05 & 1.00 & 0.23 \\
\hline v2pariglef (distance) & -0.05 & 0.14 & 0.02 & 0.14 & -0.10 & 0.23 & 1.00 \\
\hline
\end{tabular}



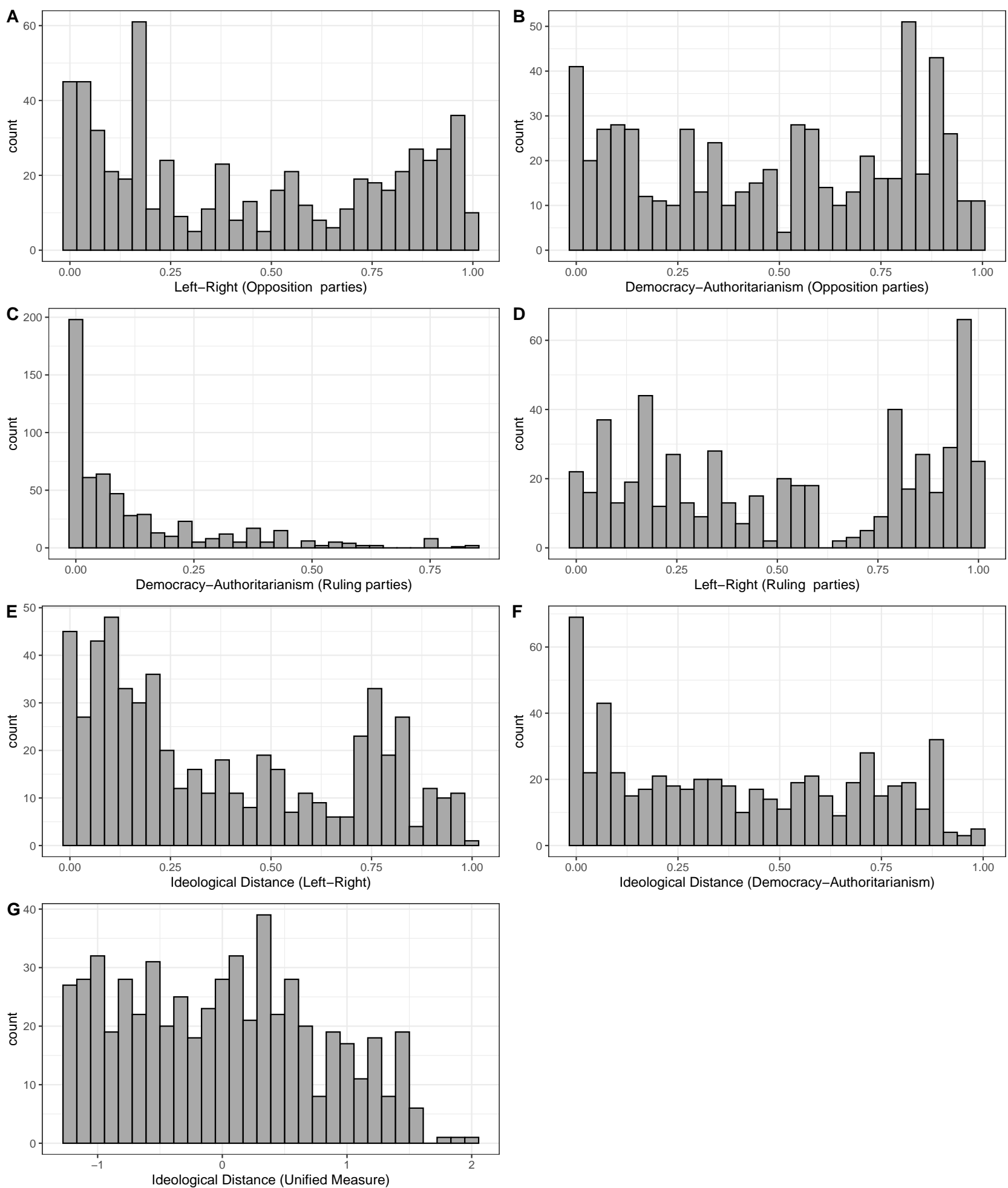

Figure 1: Ideological orientations of opposition parties and ruling parties in electoral autocracies. Note: High scores on the ideological distance index-as well as on the component variables-denote greater ideological distance. 


\section{Robustness tests}

Table 2: Excluding pre-electoral coalitions (both formal and informal).

\begin{tabular}{|c|c|c|c|c|c|c|c|}
\hline & Model 1A & Model 2A & Model 3A & Model 4A & Model 5A & Model $6 \mathrm{~A}$ & Model 7A \\
\hline & $(0.42)$ & $(0.42)$ & $(0.32)$ & $(0.33)$ & $(2.82)$ & $(2.88)$ & $(2.82)$ \\
\hline \multirow[t]{2}{*}{ Organizational extensiveness } & $-0.29^{* * *}$ & $-0.23^{* *}$ & $-0.23^{* * *}$ & $-0.22^{* * *}$ & $-0.21^{* * *}$ & $-0.22^{* * *}$ & $-0.21^{* * *}$ \\
\hline & $(0.09)$ & $(0.10)$ & $(0.07)$ & $(0.07)$ & $(0.07)$ & $(0.07)$ & $(0.07)$ \\
\hline \multirow[t]{2}{*}{ Dispersion of decision-making authority } & $-0.70^{* * *}$ & $-0.58^{* *}$ & $-0.60^{* * *}$ & $-0.64^{* * *}$ & $-0.59^{* * *}$ & $-0.55^{* * *}$ & $-0.59^{* * *}$ \\
\hline & $(0.25)$ & $(0.28)$ & $(0.21)$ & $(0.21)$ & $(0.20)$ & $(0.21)$ & $(0.20)$ \\
\hline \multirow[t]{2}{*}{ Ideological distance } & & $-1.32^{* * *}$ & $-1.16^{* * *}$ & $-1.18^{* * *}$ & $-1.20^{* * *}$ & $-1.20^{* * *}$ & $-1.19^{* * *}$ \\
\hline & & $(0.33)$ & $(0.25)$ & $(0.25)$ & $(0.25)$ & $(0.25)$ & $(0.28)$ \\
\hline \multirow[t]{2}{*}{ Previous co-optation $(\#)$} & & & $0.96^{* * *}$ & $1.02^{* * *}$ & $1.30^{* * *}$ & $1.31^{* * *}$ & $1.31^{* * *}$ \\
\hline & & & $(0.27)$ & $(0.27)$ & $(0.30)$ & $(0.30)$ & $(0.30)$ \\
\hline \multirow[t]{2}{*}{ Ethnic-regional } & & & & -0.10 & -0.11 & -0.12 & -0.10 \\
\hline & & & & $(0.43)$ & $(0.42)$ & $(0.43)$ & $(0.42)$ \\
\hline \multirow{2}{*}{ Religious } & & & & -0.83 & -0.73 & -0.80 & -0.73 \\
\hline & & & & $(0.68)$ & $(0.66)$ & $(0.66)$ & $(0.66)$ \\
\hline \multirow[t]{2}{*}{ Presidential } & & & & & 0.29 & 0.27 & 0.28 \\
\hline & & & & & $(0.64)$ & $(0.65)$ & $(0.64)$ \\
\hline \multirow[t]{2}{*}{ Electoral democracy } & & & & & -1.67 & -1.54 & -1.68 \\
\hline & & & & & $(1.51)$ & $(1.53)$ & $(1.51)$ \\
\hline \multirow[t]{2}{*}{$\log$ Oil production pc } & & & & & 0.13 & 0.13 & 0.13 \\
\hline & & & & & $(0.11)$ & $(0.12)$ & $(0.11)$ \\
\hline \multirow[t]{2}{*}{$\log$ GDP pc } & & & & & $-0.69^{* *}$ & $-0.73^{* *}$ & $-0.69^{* *}$ \\
\hline & & & & & $(0.33)$ & $(0.34)$ & $(0.33)$ \\
\hline Organizational extensiveness $\mathrm{X}$ & & & & & & -0.12 & \\
\hline Ideological distance & & & & & & $(0.09)$ & \\
\hline Dispersion of internal decision-making authority X & & & & & & & 0.03 \\
\hline Ideological distance & & & & & & & $(0.25)$ \\
\hline AIC & 509.55 & 443.43 & 434.55 & 436.62 & 428.55 & 428.99 & 430.52 \\
\hline $\mathrm{BIC}$ & 531.12 & 469.01 & 464.39 & 474.99 & 483.60 & 488.28 & 489.80 \\
\hline Log Likelihood & -249.77 & -215.71 & -210.27 & -209.31 & -201.28 & -200.50 & -201.26 \\
\hline Num. obs. & 553 & 525 & 525 & 525 & 510 & 510 & 510 \\
\hline Num. groups: party_id & 317 & 301 & 301 & 301 & 297 & 297 & 297 \\
\hline Num. groups: country_id & 64 & 63 & 63 & 63 & 62 & 62 & 62 \\
\hline Var: party_id (Intercept) & 3.12 & 3.42 & 0.49 & 0.35 & 0.14 & 0.10 & 0.13 \\
\hline Var: country_id (Intercept) & 7.54 & 6.41 & 3.53 & 3.50 & 3.04 & 3.31 & 3.03 \\
\hline
\end{tabular}

Hierarchical logit models. Standard errors in parentheses. 71 formal and informal pre-electoral coalitions are excluded. ${ }^{* * *} p<0.01$; ${ }^{* *} p<0.05 ;{ }^{*} p<0.1$. 
Table 3: Controlling for opposition party seat share and party age.

\begin{tabular}{|c|c|c|c|}
\hline & Model 8A & Model 9A & Model 10A \\
\hline Organizational extensiveness & $\begin{array}{c}-0.24^{* * *} \\
(0.08)\end{array}$ & $\begin{array}{c}-0.26^{* * *} \\
(0.09)\end{array}$ & $\begin{array}{c}-0.24^{* * *} \\
(0.08)\end{array}$ \\
\hline Dispersion of decision-making authority & $\begin{array}{c}-0.57^{* * *} \\
(0.20)\end{array}$ & $\begin{array}{c}-0.52^{* *} \\
(0.21)\end{array}$ & $\begin{array}{c}-0.58^{* * *} \\
(0.20)\end{array}$ \\
\hline Ideological distance & $\begin{array}{c}-1.32^{* * *} \\
(0.24)\end{array}$ & $\begin{array}{c}-1.30^{* * *} \\
(0.24)\end{array}$ & $\begin{array}{c}-1.37^{* * *} \\
(0.28)\end{array}$ \\
\hline Previous co-optation $(\#)$ & $\begin{array}{c}1.27^{* * *} \\
(0.29)\end{array}$ & $\begin{array}{c}1.31^{* * *} \\
(0.30)\end{array}$ & $\begin{array}{c}1.27^{* * *} \\
(0.29)\end{array}$ \\
\hline Ethnic-regional & $\begin{array}{c}0.24 \\
(0.42)\end{array}$ & $\begin{array}{c}0.20 \\
(0.42)\end{array}$ & $\begin{array}{c}0.22 \\
(0.42)\end{array}$ \\
\hline Religious & $\begin{array}{l}-1.07^{*} \\
(0.60)\end{array}$ & $\begin{array}{c}-1.19^{* *} \\
(0.60)\end{array}$ & $\begin{array}{l}-1.08^{*} \\
(0.60)\end{array}$ \\
\hline Presidential & $\begin{array}{c}0.27 \\
(0.64)\end{array}$ & $\begin{array}{c}0.28 \\
(0.65)\end{array}$ & $\begin{array}{c}0.28 \\
(0.64)\end{array}$ \\
\hline Electoral democracy & $\begin{array}{l}-1.54 \\
(1.52)\end{array}$ & $\begin{array}{l}-1.24 \\
(1.53)\end{array}$ & $\begin{array}{l}-1.51 \\
(1.52)\end{array}$ \\
\hline $\log$ Oil production pc & $\begin{array}{c}0.14 \\
(0.11)\end{array}$ & $\begin{array}{c}0.14 \\
(0.12)\end{array}$ & $\begin{array}{c}0.14 \\
(0.11)\end{array}$ \\
\hline $\log$ GDP pc & $\begin{array}{c}-0.74^{* *} \\
(0.33)\end{array}$ & $\begin{array}{c}-0.77^{* *} \\
(0.33)\end{array}$ & $\begin{array}{c}-0.73^{* *} \\
(0.33)\end{array}$ \\
\hline log Opposition party seat share & $\begin{array}{c}0.22 \\
(0.20)\end{array}$ & $\begin{array}{c}0.26 \\
(0.21)\end{array}$ & $\begin{array}{c}0.23 \\
(0.21)\end{array}$ \\
\hline log Opposition party age & $\begin{array}{l}-0.06 \\
(0.14)\end{array}$ & $\begin{array}{l}-0.08 \\
(0.14)\end{array}$ & $\begin{array}{l}-0.06 \\
(0.14)\end{array}$ \\
\hline $\begin{array}{l}\text { Organizational extensiveness X } \\
\text { Ideological distance }\end{array}$ & & $\begin{array}{c}-0.17^{*} \\
(0.09)\end{array}$ & \\
\hline $\begin{array}{l}\text { Dispersion of internal decision-making authority X } \\
\text { Ideological distance }\end{array}$ & & & $\begin{array}{l}-0.11 \\
(0.25)\end{array}$ \\
\hline AIC & 469.41 & 468.17 & 471.26 \\
\hline $\mathrm{BIC}$ & 534.25 & 537.33 & 540.42 \\
\hline Log Likelihood & -219.70 & -218.09 & -219.63 \\
\hline Num. obs. & 557 & 557 & 557 \\
\hline Num. groups: party_id & 308 & 308 & 308 \\
\hline Num. groups: country_id & 62 & 62 & 62 \\
\hline Var: party_id (Intercept) & 0.38 & 0.26 & 0.40 \\
\hline Var: country_id (Intercept) & 3.09 & 3.48 & 3.12 \\
\hline
\end{tabular}

Hierarchical logit models. Standard errors in parentheses. ${ }^{* * *} p<0.01{ }^{* *} p<0.05$; ${ }^{*} p<0.1$. 
Table 4: Controlling for additional country-level variables and region dummies.

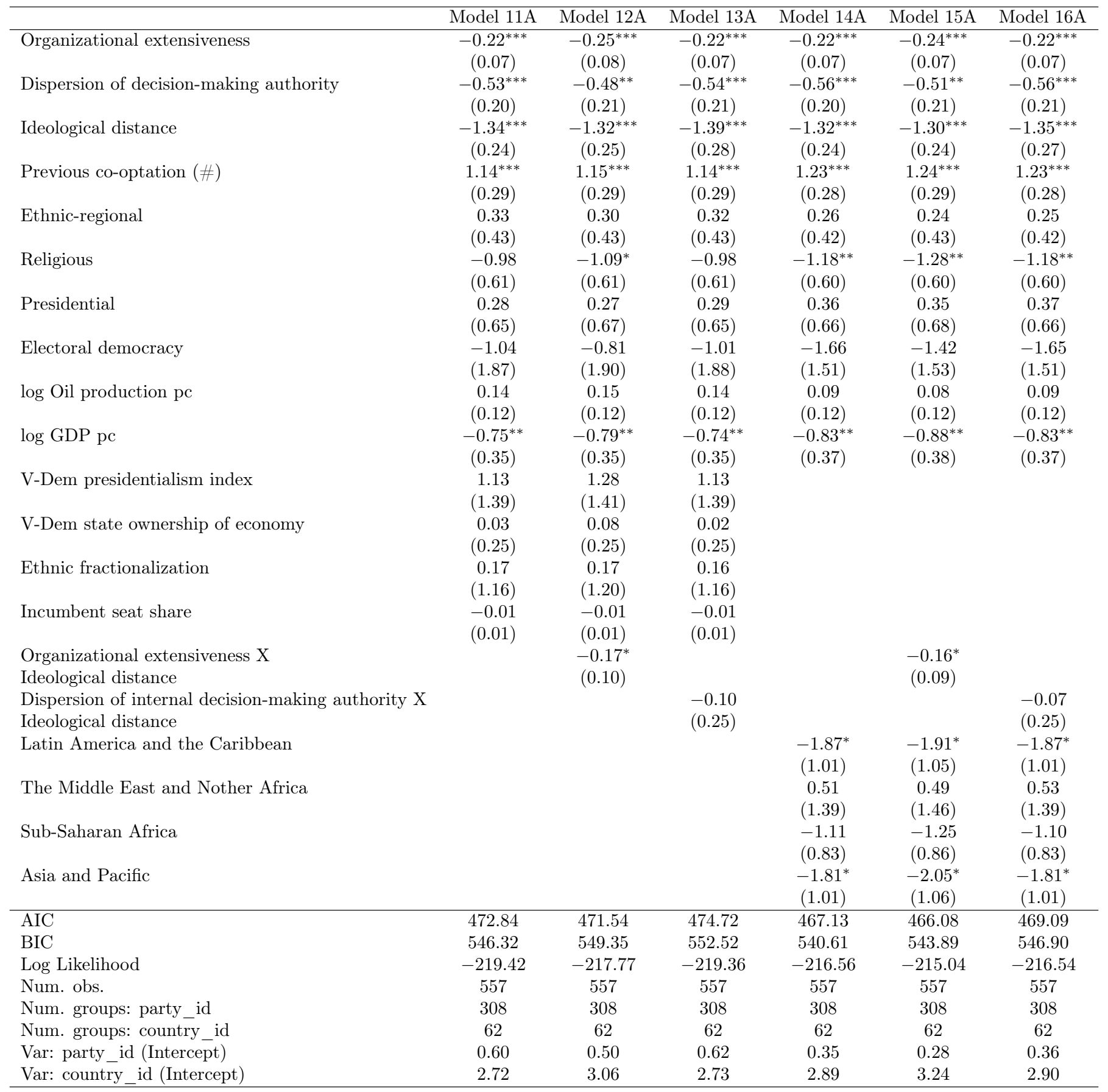

Hierarchical logit models. Standard errors in parentheses. ${ }^{* * *} p<0.01 ;{ }^{* *} p<0.05 ;{ }^{*} p<0.1$. 
Table 5: Replication of Table 1 in the Main Text Using Multiple Imputation.

\begin{tabular}{|c|c|c|c|c|c|c|}
\hline & Model 17A & Model 18A & Model 19A & Model 20A & Model 21A & Model 22A \\
\hline Organizational extensiveness & $\begin{array}{c}-0.31^{* * *} \\
(0.10)\end{array}$ & $\begin{array}{c}-0.23^{* *} \\
(0.10)\end{array}$ & $\begin{array}{c}-0.22^{* * *} \\
(0.07)\end{array}$ & $\begin{array}{l}-0.21^{* * *} \\
(0.07)\end{array}$ & $\begin{array}{c}-0.23^{* * *} \\
(0.07)\end{array}$ & $\begin{array}{c}-0.21^{* * *} \\
(0.07)\end{array}$ \\
\hline Dispersion of decision-making authority & $\begin{array}{c}-0.70^{* *} \\
(0.29)\end{array}$ & $\begin{array}{c}-0.52^{* *} \\
(0.26)\end{array}$ & $\begin{array}{c}-0.59^{* * *} \\
(0.19)\end{array}$ & $\begin{array}{l}-0.57^{* * *} \\
(0.19)\end{array}$ & $\begin{array}{c}-0.53^{* * *} \\
(0.19)\end{array}$ & $\begin{array}{l}-0.59^{* * *} \\
(0.19)\end{array}$ \\
\hline Ideological distance & & $\begin{array}{c}-1.47^{* * *} \\
(0.32)\end{array}$ & $\begin{array}{c}-1.33^{* * *} \\
(0.23)\end{array}$ & $\begin{array}{l}-1.34^{* * *} \\
(0.23)\end{array}$ & $\begin{array}{l}-1.35^{* * *} \\
(0.23)\end{array}$ & $\begin{array}{l}-1.42^{* * *} \\
(0.26)\end{array}$ \\
\hline Previous co-optation (\#) & & & $\begin{array}{c}0.98^{* * *} \\
(0.25)\end{array}$ & $\begin{array}{c}1.08^{* * *} \\
(0.26)\end{array}$ & $\begin{array}{c}1.08^{* * *} \\
(0.25)\end{array}$ & $\begin{array}{c}1.08^{* * *} \\
(0.26)\end{array}$ \\
\hline Religious & & & $\begin{array}{c}-1.25^{* *} \\
(0.60)\end{array}$ & $\begin{array}{c}-1.30^{* *} \\
(0.59)\end{array}$ & $\begin{array}{c}-1.47^{* *} \\
(0.59)\end{array}$ & $\begin{array}{c}-1.32^{* *} \\
(0.59)\end{array}$ \\
\hline Presidential & & & & $\begin{array}{c}0.34 \\
(0.62)\end{array}$ & $\begin{array}{c}0.40 \\
(0.63)\end{array}$ & $\begin{array}{c}0.36 \\
(0.62)\end{array}$ \\
\hline Electoral democracy & & & & $\begin{array}{l}-1.51 \\
(1.45)\end{array}$ & $\begin{array}{l}-1.42 \\
(1.40)\end{array}$ & $\begin{array}{l}-1.47 \\
(1.45)\end{array}$ \\
\hline $\begin{array}{l}\text { Organizational extensiveness X } \\
\text { Ideological distance }\end{array}$ & & & & & $\begin{array}{l}-0.15^{*} \\
(0.09)\end{array}$ & \\
\hline $\begin{array}{l}\text { Dispersion of internal decision-making authority X } \\
\text { Ideological distance }\end{array}$ & & & & & & $\begin{array}{l}-0.15 \\
(0.23)\end{array}$ \\
\hline $\mathrm{AIC}$ & 564.38 & 526.66 & 515.43 & 516.21 & 514.53 & 517.79 \\
\hline $\mathrm{BIC}$ & 586.40 & 553.08 & 555.06 & 573.46 & 571.78 & 579.44 \\
\hline Log Likelihood & -277.19 & -257.33 & -248.71 & -245.11 & -244.27 & -244.89 \\
\hline Num. obs. & 604 & 604 & 604 & 604 & 604 & 604 \\
\hline Num. groups: party_id & 328 & 328 & 328 & 328 & 328 & 328 \\
\hline Num. groups: country_id & 64 & 64 & 64 & 64 & 64 & 64 \\
\hline Var: party_id (Intercept) & 6.18 & 4.67 & 0.54 & 0.45 & 0.34 & 0.46 \\
\hline
\end{tabular}

Hierarchical logit models. Standard errors in parentheses. ${ }^{* * *} p<0.01 ;{ }^{* *} p<0.05 ;{ }^{*} p<0.1$. 